\title{
VÁRY MIKLÓS
}

\section{A hiszterézis közgazdasági jelentőségéről posztkeynesi szemléletben}

\begin{abstract}
A 2008-as gazdasági világválságot követő kilábalás során megfigyelhető, hogy a gazdaságok többsége nem tér vissza a válság előtti növekedési pályájára, hanem egy tartósan alacsonyabb szintüre áll rá. A jelenség az egyik legnépszerübb magyarázat szerint a gazdasági dinamika egy máig kevés figyelmet kapott típusának, a hiszterézisnek egy konkrét megnyilvánulása. Dinamikus rendszerekben akkor figyelhető meg hiszterézis, ha egy átmeneti sokk permanens hatást gyakorol a rendszer hosszú távú egyensúlyára. A tanulmány áttekintést nyújt a hiszterézis közgazdasági szakirodalmáról, és amellett érvel, hogy a gazdasági dinamika elemzésében nagyobb szerepet kellene szánni a hiszterézis modelljeinek. Összefoglalja a hiszterézis közgazdasági elmélettörténetét, értelmezi a jelentőségét a posztkeynesi közgazdaságtan szemszögéből, és példákkal szemléltetve bemutatja a hiszterézis alapvető közgazdasági modelljeit, típusait és azok tulajdonságait. A tanulmány ismerteti a föáramú közgazdaságtan hiszterézissel kapcsolatos gondolatait is, de amellett érvel, hogy a hiszterézis közgazdasági jelentősége a posztkeynesi közgazdaságtan nézőpontjából érthető meg igazán.* Journal of Economic Literature (JEL) kód: B22, B59, C61, E12, E32.
\end{abstract}

\section{A hiszterézis aktualitása a 2008-as gazdasági világválság tükrében}

A 2008-as gazdasági világválság utáni lassú kilábalás és az új neoklasszikus szintézis

A 2008-as világgazdasági válság eseményei kezdettől fogva számos ponton megkérdőjelezték a föáramú közgazdaságtan megingathatatlannak hitt elméleteit. A válság egyik legnagyobb rejtélyének kibontakozására azonban egészen napjainkig kellett

\footnotetext{
* Köszönettel tartozom Mellár Tamásnak, Balatoni Andrásnak, Barancsuk Jánosnak, Németh Kristófnak és a két anonim lektornak a tanulmány korábbi változataihoz füzött értékes megjegyzéseikért. Köszönöm továbbá a Pallas Athéné Domus Educationis Alapítvány szakmai és anyagi támogatását.

A kutatást az Emberi Erőforrások Minisztériumának Felsőoktatási Intézményi Kiválósági Programja finanszírozta, a Pécsi Tudományegyetem 4. tématerületi „A hazai vállalatok szerepének növelése a nemzet újraiparosításában” programja keretében (szerződés száma: 20765-3/2018/FEKUTSTRAT).
}

Váry Miklós tudományos segédmunkatárs, Pécsi Tudományegyetem Közgazdaságtudományi Kar

(e-mail: varym@ktk.pte.hu).

A kézirat első változata 2018. január 23-án érkezett szerkesztőségünkbe.

DOI: http://dx.doi.org/10.18414/KSZ.2018.10.1006 
várni, amikorra a legtöbb fejlett gazdaság már kilábalt a recesszióból. Hiszen a gazdaságok többsége nem a válság előtti növekedési pályájára állt vissza, hanem egy ahhoz képest tartósan alacsonyabb szintü, sőt számos esetben alacsonyabb növekedési rátával is jellemezhető növekedési pályára. Ez magyarázható úgy, hogy a válság jelentette negatív sokk mint rövid távú, átmeneti gazdasági megrázkódtatás permanens hatást gyakorolt a gazdaságok müködésére, hosszú távú veszteségeket okozva. Ezt a jelenséget hiszterézisnek szokás nevezni.

Bár a hiszterézis fogalma nem újdonság a közgazdaságtanban, napjainkig a tudomány perifériájára szorult, a főáramú makrogazdasági elméletekkel pedig nehezen összeegyeztethető. A makroökonómiát uraló új neoklasszikus szintézis szerint egy olyan, átmeneti negatív keresleti sokkot követően, amilyen a 2008-as válság is volt, a piaci mechanizmusok hosszú távon visszaterelik a gazdaságot a sokkot megelőző egyensúlyi (potenciális) növekedési pályára (Woodford [2003], Galí [2008]). A konvergencia sebessége természetesen függ a gazdaság strukturális jellemzőitől, a piaci súrlódások mértékétől és a recesszió idején folytatott gazdaságpolitikától, de a válság előtti növekedési pályára való visszatérés hosszú távon ezektől függetlenül megvalósul.

Mindezt elméletileg az biztosítja, hogy a GDP hosszú távú növekedési pályáját más tényezők határozzák meg, mint a rövid távú ingadozásait: hosszú távon a kínálati oldal dominál, a potenciális növekedési pályát a technológiai haladás és a népességnövekedés ütemei határozzák meg, amelyek függetlenek a keresleti sokkok hatásaitól. Utóbbiak csupán a GDP ciklikus ingadozásait képesek befolyásolni a különböző piaci súrlódások miatt, amelyek megakadályozzák, hogy az aggregált kereslet és kínálat időbeli késlekedés nélkül alkalmazkodhasson egymáshoz. Hoszszú távon azonban a súrlódások nem képesek útját állni a piaci ármechanizmusnak, ezért az hozzáigazítja az aggregált kereslet növekedését a kínálati oldalról meghatározott egyensúlyi növekedési pályához. Ez a kettősség - tudniillik, hogy a gazdaság másképpen müködik rövid és hosszú távon - képezi az új neoklasszikus szintézis alapját, hiszen egyben azt jelenti, hogy rövid távon az újkeynesiánusok elképzelései szerint müködik a gazdaság, hosszú távon viszont az újklasszikusok elméleteinek megfelelően (Mellár [2010]).

$\mathrm{Az}$ 1. ábra szemlélteti, hogy a válságból történő kilábalás alapjaiban kérdőjelezte meg az új neoklasszikus szintézis központi gondolatát. ${ }^{1} \mathrm{Az}$ ábrán a reál-GDP időbeli alakulása látható három kiragadott ország és az Európai Unió egésze (28 tagállam) esetében 2000 első negyedévétől 2017 második negyedévéig. Ezenkívül feltüntettük a GDP kétféle módon számított trendidősorát is. A pontozott vonal a teljes mintán alkalmazott, Hodrick-Prescott-szűrővel számított trendértékeket tartalmazza, a szaggatott vonal viszont csak a válság elötti, a 2007 negyedik negyedévéig tartó részmintán futtatott, a Hodrick-Prescott-szűrővel számolt

\footnotetext{
${ }^{1}$ Az 1. ábra készítéséhez Ball [2014] számítási módszerét vettük alapul, némileg módosított formában, ugyanis a potenciális növekedési pályára vonatkozó becsléseket nem az OECD-től kölcsönöztük, hanem mi állítottuk elő őket Hodrick-Prescott-szűrővel. Ez kevésbé kifinomult módszer, mint az OECD által alkalmazott, termelési függvényen alapuló becslési eljárás, de illusztráció céljára bőven elegendő.
} 


\section{1. ábra}

A reál-GDP és trendértékeinek alakulása Németországban, az Egyesült Államokban, az Európai Unióban és Magyarországon, 2000. I. negyedév-2017. II. negyedév (szezonálisan kiigazított, évesített negyedéves adatok, 2010-es árakon)
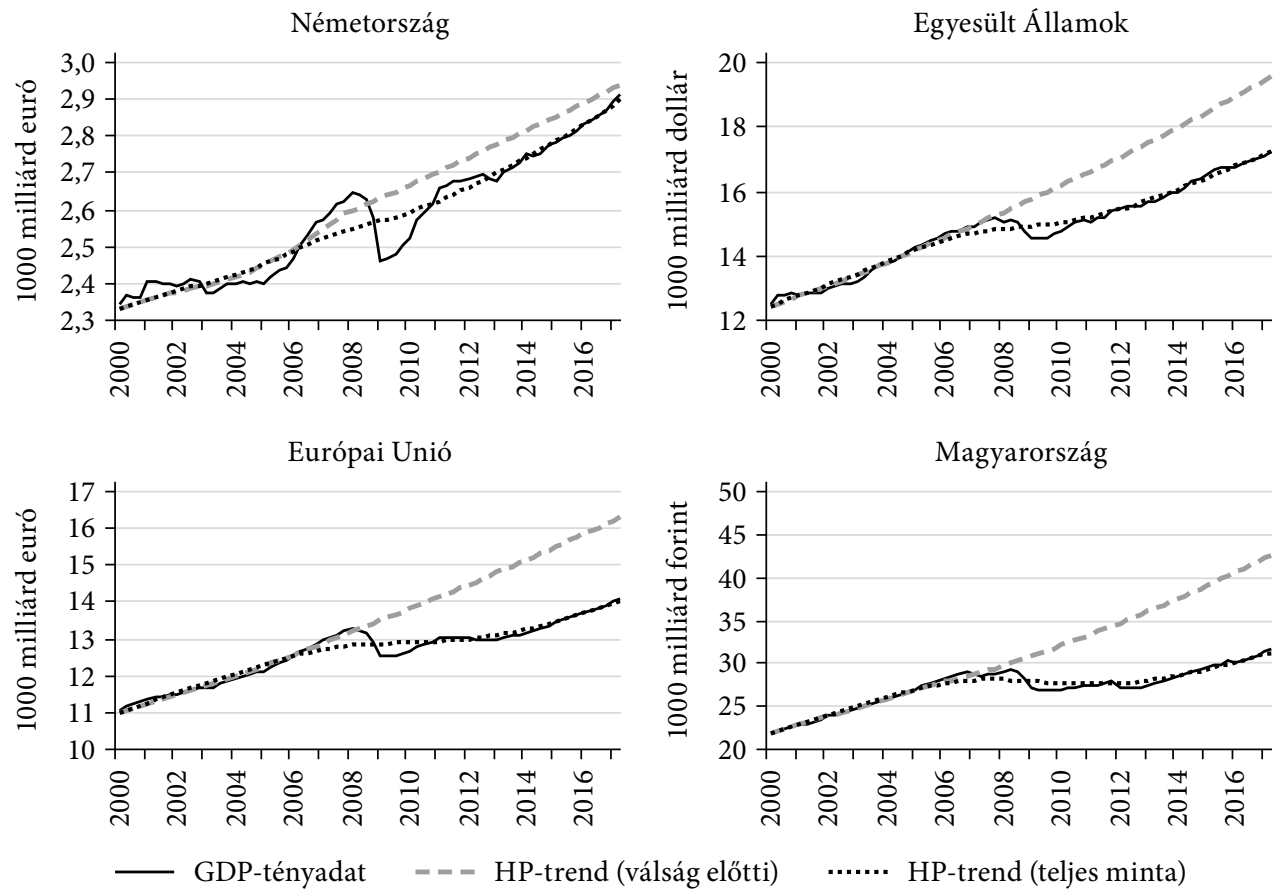

Forrás: saját számítás és szerkesztés az Eurostat és a Bureau of Economic Analysis adatai alapján.

értékeket mutatja. ${ }^{2}$ A 2008 első negyedévével kezdődő időszakra loglineáris extrapolációval elörevetítettük az így kapott trendet. Tehát a szaggatott vonal annak a trendpályának a közelítése, amely mentén a válság elmaradása esetén növekedett volna a GDP.

Látható, hogy a válságból való kilábalás gazdaságonként eltérő jellegzetességeket mutat. A német gazdaság adatai alapján például nehéz lenne cáfolni a tankönyvi alkalmazkodási mechanizmust. Bár a teljes mintán számított növekedési pálya Németországban is évekig elmaradt a válság elöttitől, az elmaradás nem volt kirívó mértékü, ráadásul a két trendpálya elkezdett konvergálni egymáshoz, és 2017 második negyedévére a GDP gyakorlatilag visszatért a válság előtti növekedési pályájára, ahogy az új neoklasszikus szintézis elmélete jósolta. Ezzel szemben az Egyesült Államokban a válság láthatóan egy alacsonyabb szintű növekedési pályára lökte a gazdaságot, ami nem látszik konvergálni a válság előtti trendhez. Ezt a megfigyelést számos közgazdász hiszterézisként értelmezte: egy átmeneti negatív keresleti sokk a

\footnotetext{
${ }^{2}$ Mindkét trendpálya számításához felhasználtuk az 1999-es év négy negyedévének GDP-adatait is, az eredmények értékeléséhez azonban nem használtuk őket. Így legalább a minta egyik végén csökkenthető valamelyest a Hodrick-Prescott-szűrő közismert végponti bizonytalansága.
} 
GDP hosszú távú, potenciális növekedési pályáját is visszavetette. Ez megkérdőjelezi az új neoklasszikus szintézis központi gondolatát, amely szerint egy gazdaság hoszszú távú növekedési pályája független a GDP rövid távú ingadozásaitól. Még súlyosabb a helyzet az Európai Unió egészében, és különösen a magyar gazdaságban. Itt a GDP teljes mintán számított trendpályája látványosan divergál a válság előtti trendtől, tehát a válság nem csupán egy alacsonyabb szintre lökte a potenciális növekedési pályát, hanem a potenciális növekedési ütemet is visszavetette. Ezt a jelenséget nevezi Blanchard és szerzőtársai [2015] szuperhiszterézisnek.

A potenciális kibocsátásban bekövetkezett veszteségek számszerüen is jelentősek. Ball [2014] 23 OECD-tagország adatai alapján 0-tól több mint 30 százalékig terjedő veszteségeket jelzett előre 2015-ig bezárólag. A gazdaságok méretével súlyozott átlagos veszteség 8,4 százalék. Hall [2014] számításai szerint az amerikai GDP 2013-ban 13 százalékkal maradt el a válság előtti trendpályájától. Mellár-Németh [2018] egy Kálmán-szűrővel becsült, többváltozós, kvázistrukturális állapottérmodell segítségével arra a következtetésre jutott, hogy a válságot követően nagyjából megfeleződött a magyar gazdaság potenciális növekedési üteme a 2003 eleji ütemhez képest. Ez jelentős szuperhiszterézisre utalhat.

Hozzá kell tenni azonban, hogy a GDP Hodrick-Prescott-szürővel meghatározott, 1. ábrán látható trendpályái nem biztos, hogy értelmezhetők potenciális növekedési pályaként, hiszen a válságot megelőző dinamikus gazdasági növekedést a legtöbb gazdaságban eladósodás finanszírozta, ezért nem bizonyult fenntarthatónak. A hivatkozott tanulmányok mégis hasonlóan egyszerü módszerekkel közelítik a potenciális növekedési pályát. Léteznek a Kálmán-szűrőn alapuló többváltozós, kvázistrukturális módszerek is a potenciális kibocsátás becslésére, amelyek alkalmasak arra, hogy a különböző pénzügyi változókban rejlő információt figyelembe vegyék a becslés során (Borio és szerzőtársai [2017]). Mellár-Németh [2018] ilyen módszerek felhasználásával is hiszterézisre utaló jeleket talált a magyar gazdaság potenciális kibocsátásában, tehát a lényegi következtetést valószínűleg nem befolyásolja a Hodrick-Prescott-szürő alkalmazása, az 1. ábra célja csupán az illusztráció. Az egyszerűség kedvéért a továbbiakban is a potenciális növekedési pályák közelítéseként fogom értelmezni az 1. ábrán feltüntetett trendpályákat - észben tartva, hogy azok minden bizonnyal pontatlan közelítések.

Ball [2009] tanulmánya alapján világos, hogy a hiszterézis nem csak a 2008-as válságból történő kilábalás sajátossága. A szerző logikája szerint a munkanélküliség természetes rátájának és az inflációnak az ellentétes irányú mozgása utal hiszterézisre. Ha ugyanis egy átmeneti negatív (pozitív) keresleti sokk növeli (csökkenti) a munkanélküliséget, akkor annak a Phillips-görbe alapján dezinflációs (inflációs) hatása lesz. Ha pedig hiszteretikus hatása is van a sokknak, akkor a természetes rátának is nőnie (csökkennie) kell mindeközben. Tehát amennyiben azt látjuk az empirikus idősorokban, hogy a természetes ráta növekedése (csökkenése) dezinflációval (inflációval) jár együtt, akkor az arra utal, hogy átmeneti keresleti sokkok permanens hatást gyakorolnak a munkanélküliség természetes rátájára, amelynek a dinamikájában ezek szerint hiszterézis figyelhető meg.

Ball [2009] 20 OECD-tagország 1980-2007 közötti adatait vizsgálva azt figyelte meg, hogy a munkanélküliség természetes rátájának 3 százalékpontnál nagyobb növekedései kivétel nélkül jelentős dezinflációval jártak együtt, 3 százalékpontnál nagyobb 
csökkenéseit pedig kilencből öt esetben az infláció megugrásai kísérték. Mindez arra utal, hogy jelen van a hiszterézis a munkanélküliség dinamikájában. Ki kell emelni, hogy az inflációt kiváltó pozitív keresleti sokkok által előidézett hiszterézisre utaló bizonyíték kevésbé meggyőző, mint a dezinflációt kiváltó negatív keresleti sokkok esetében. Az empirikus szakirodalom egészét tekintve is nyitott kérdés, hogy vajon a hiszterézis szimmetrikus jelenség-e, tehát pozitív irányban is képes-e müködni. A hivatkozott tanulmányok jellemzően válságok következményeként mutatják ki a hiszterézist, nem pedig konjunkturális időszakok permanens pozitív hatásaként.

Blanchard és szerzőtársai [2015] szintén válságokat követő időszakokat vizsgált, és akárcsak Ball [2009], ez a tanulmány is alátámasztotta, hogy a hiszterézis nem csak a 2008-as válság kapcsán felbukkanó, egyedi jelenség. A szerzők 22 fejlett ország 122 recesszióját vizsgálták meg az 1970-2010 közti időszakban, és a válság előtti, valamint a válság utáni növekedési trendpályák összevetése alapján a recessziók nagyjából kétharmadában hiszterézist találtak. Ezen válságok körülbelül felében a szuperhiszterézis jelensége is megfigyelhető volt.

\section{A 2008-as válság utáni lassú kilábalás alternatív magyarázatai}

Az 1. ábrán látható jelenségnek csak egy lehetséges magyarázata a hiszterézis: felmerültek más, alternatív magyarázatok is. A legkézenfekvőbb ellenérv szerint a 2008as válság nem átmeneti, hanem permanens sokk volt. A permanens sokkok pedig hiszteretikus dinamika hiányában is permanens hatásokkal járnak. Ebbe az értelmezési keretbe illeszkedik a tartós stagnálás modellje (Eggertsson-Mehrotra [2014]), amelyben a háztartások adósságkorlátjának permanens szigorodása a megtakarítások kínálatának növekedéséhez vezet, aminek következtében a természetes reálkamatláb negatív tartományba süllyedhet. Erre a jegybank nem tud megfelelően reagálni a kamatláb nulla alsó korlátja miatt, így tartósan fennmarad a túlkínálat a tôkepiacon, a termékpiacon pedig az aggregált kereslet elégtelensége válik krónikussá, ezáltal a kibocsátás állandósult állapotban a potenciális érték alatt ragad.

A valóságban természetesen nem marad örökké effektív az adósságkorlát. Koo [2011] mérlegválság-megközelítésében szintén az adósságkorlát szigorodásával lép recesszióba a gazdaság, ami itt nem exogén sokk, hanem egy endogén dinamika eredménye: a válságot megelöző konjunktúra időszakának túlzott eladósodása kényszeríti ki az adósságállomány leépítését, ami időigényes folyamat, ráadásul jelentős keresletet von ki a gazdaságból, ami által az még mélyebb recesszióba kerül, tovább nyújtva a mérlegkiigazítás folyamatát. Azonban Koo [2011] szerint az adósságleépítés egyszer véget ér, ami lehetővé teszi a visszatérést a válság előtti növekedési pályára. Az ő elméletében tehát nincs hiszterézis, csak egy hosszan elhúzódó recesszió. Ennek megfelelően lehetséges, hogy az 1. ábrán látható jelenség sem hiszterézis, hanem egyszerüen nem telt még el annyi idő a válság kezdete óta, hogy befejeződhessen a mérlegkiigazítás és a visszatérés a válság előtti növekedési pályára.

Hasonló ellenérvnek tekinthető a hiszterézissel szemben a pénzügyi ciklusok elmélete (Borio [2014]), amely szerint a hagyományos gazdasági ciklus mellett az 
úgynevezett pénzügyi ciklus is jelentősen befolyásolja a gazdaságok ciklikus ingadozásait. A pénzügyi ciklus a hitel/GDP arány és az ingatlanárak alakulásával ragadható meg legjobban, amplitúdója nagyobb, frekvenciája pedig kisebb, mint a hagyományos gazdasági ciklusé. (A hagyományos gazdasági ciklus hossza jellemzően 1-8 év, a pénzügyi ciklusok átlagos hossza viszont körülbelül 16 év.) Ennek a hátterében szintén a válság előtti túlhitelezésből adódó túlfütöttség és az általa kiváltott, elhúzódó mérlegkiigazításokból következö túlhütöttség áll. A legtöbb pénzügyi válsághoz hasonlóan a 2008. évi válság is a pénzügyi ciklus tetőpontján következett be, ami után a pénzügyi ciklus alacsony frekvenciája miatt hosszú időre van szükség ahhoz, hogy a GDP visszatérhessen a válság előtti növekedési pályájára. Lehet, hogy nem hiszterézist látunk az 1. ábrán, hanem egyszerüen nem telt el elég idő ahhoz 2008 óta, hogy a pénzügyi ciklus felszálló ágára kerüljenek a gazdaságok. Van azonban egy fontos tény, ami az ellen szól, hogy pusztán Koo [2011] mérlegválság-megközelítése vagy Borio [2014] pénzügyiciklus-elmélete alapján értelmezzük az 1. ábrát: a feltüntetett idősorok 2017 második negyedévéig terjednek, amikor már közel kilenc év telt el a Lehman Brothers bukása óta. Ennyi idő alatt a GDP-nek már el kellett volna kezdenie konvergálni a válság előtti növekedési pályához, azonban ennek nyomát sem látjuk a gazdaságok többségében, tehát az elhúzódó mérlegkiigazításokon és az alacsony frekvenciájú pénzügyi cikluson túl kell lennie valamilyen további mechanizmusnak is a háttérben.

A hiszterézis gondolatához legközelebb álló másik magyarázat a CecchettiKharroubi [2015] tanulmányhoz füződik, amely szerint a pénzügyi szektor válság előtti növekedése a reálerőforrások nem optimális allokációjához vezetett, amelynek korrigálása időigényes, ezért tartósan visszavetette a gazdaságok növekedési ütemét. A szerzőpáros elmélete szerint amennyiben a pénzügyi szektor elszívja a képzett munkaerőt a vállalkozók elől, olcsóbban tud hitelezni. Ez arra ösztönzi a vállalkozókat, hogy olyan projektekbe (például építkezésekbe) vágjanak bele, amelyek könnyen jutnak forráshoz. Ezeknek a hozamát könnyü fedezetként felajánlani, viszont a termelékenységnövekedéshez kevésbé járulnak hozzá, emiatt nem is igényelnek képzett munkaerőt, amit így a pénzügyi szektor még könnyebben tud elcsábítani. Ha viszont kezdetben a vállalkozók alkalmazzák a képzett munkaerőt, akkor magas hozamú projekteket indítanak, amelyek eredménye nehezebben ajánlható fel fedezetként, de jelentősen hozzájárulnak a termelékenységnövekedéshez. Megfelelö fedezet hiányában a pénzügyi szektor számára kisebb az ösztönzés a hitelezésre, így még kevesebb képzett munkaerőre lesz szüksége, s ezáltal a képzett munkaerő még akadálytalanabbul tud áramlani a vállalkozói szektorba.

A modellben tehát két stabil egyensúly alakul ki: az egyikben a pénzügyi szektor alkalmazza a képzett munkaerőt, a másikban a vállalkozók. Jóléti szempontból az utóbbi optimális, hiszen az jár nagyobb termelékenység- és gazdasági növekedéssel. A válság mégsem hozta el az optimális egyensúlyt, ami akkor fordulhat elö, ha kezdetben a pénzügyi szektor alkalmazza a képzett munkaerő nagyobb hányadát. Ehhez pedig arra van szükség, hogy a pénzügyi szektor alkuereje nagyobb legyen a vállalkozókénál, ezáltal magasabb béreket tudjon fizetni. A pénzügyi szektor válság előtti növekedésének időszakában valószínűleg ez volt a helyzet. A többszörös egyensúly jelenléte miatt a gazdaság dinamikája útfüggővé válik: a reálerőforrások 
kezdeti allokációja határozza meg, hogy melyik egyensúlyi allokáció felé konvergál a gazdaság. A többes egyensúly által meghatározott, útfüggő dinamika viszont nem hiszterézis, hanem az útfüggőség egy másfajta megnyilvánulási formája. ${ }^{3}$

Összegezve kijelenthető, hogy az 1. ábrán látható lassú kilábalás többféleképpen is magyarázható, ám egyelöre nem létezik egy domináns értelmezés. Sőt a lehetséges magyarázatok egyáltalán nem zárják ki egymást, mindegyik szerepet játszhat a válság utáni lassú kilábalásban. A hiszterézisen alapuló magyarázat tehát semmiképpen sem tekinthető alsóbbrendünek a többihez képest, ez az egyik legerősebb ismert értelmezése a 2008-as válságot követő lassú kilábalásnak. A tanulmányban kizárólag ezzel foglalkozunk, elismerve a többi lehetséges interpretáció létjogosultságát is.

\section{A hiszterézis gazdaságpolitikai implikációi}

A hivatkozott tanulmányok egyhangúlag kiemelik, hogy a hiszterézisnek kulcsfontosságú implikációi vannak a monetáris politika számára. Ezt támasztja alá az is, hogy a Magyar Nemzeti Bank 2016-os Növekedési jelentésének egyik központi témájául a hiszterézis gazdaságpolitikai következményeit választotta (MNB [2016]). A hiszterézis legfontosabb tanulsága a jegybankok számára az, hogy nem lehet optimális a szigorú inflációs célkövetési politika abban az esetben, ha átmeneti negatív keresleti sokkok tartósan visszavetik a potenciális kibocsátást. Ilyenkor az infláció megugrására adott erőteljes, restriktív monetáris politikai reakció permanens reálgazdasági veszteséget okozhat, amit nem képes kompenzálni a dezinfláció haszna. Ez azt jelenti, hogy a jegybankoknak nagyobb hangsúlyt kell fektetniük a reálgazdasági célok követésére az infláció stabilizálása mellett a kamatdöntéseik során. Galí [2015] hozzátette, hogy a munkanélküliség stabilizálása azért is különösen fontos a jegybankok számára, mert hiszterézis jelenlétében a munkanélküliség természetes rátája együtt ingadozik a tényleges munkanélküliséggel, ezért jegybanki stabilizáció nélkül elvesztené a várakozásokat horgonyzó szerepét. Stockhammer-Sturn [2012] 19 OECD-tagország 40 recesszióját vizsgálta az 1980-2007 közötti időszakban. Ball [1999] elemzéseit kiterjesztve és eredményeit megerősítve, arra a következtetésre jutott, hogy azokban a válságokban, amelyek idején a monetáris politika nem lazított eléggé, vagy megszorított, jellemzően nagyobb mértékü hiszterézis volt tapasztalható.

Ball [2015] szerint a válság utáni fellendülés megindulásával a jegybankoknak nem kellene azonnal kamatemelésbe kezdeniük, hanem egy „magas nyomású gazdaságot” (high-pressure economy) kellene kialakítaniuk, amelyben engedik, hogy az infláció a célérték fölé, a munkanélküliség pedig a természetes ráta alá kerüljön. ${ }^{4}$ Ezt azzal indokolja, hogy Ball [2009] bizonyítékai alapján a hiszterézis pozitív irányban is képes müködni, vagyis a konjunkturális időszakok is tartósan csökkenthetik a természetes

\footnotetext{
${ }^{3}$ Az útfüggőség és a hiszterézis viszonyrendszeréről bővebb fejtegetés található $A$ hiszterézis helye a postkeynesi közgazdaságtan gondolati rendszerében címü alfejezetben.

${ }^{4}$ A magas nyomású gazdaság fogalma eredetileg Okun [1973] nevéhez füződik, Ball [2015] az ő gondolatait aktualizálta a közelmúlt gazdasági válságának összefüggésében.
} 
munkanélküliséget. ${ }^{5}$ Tehát a magas nyomású gazdaság segítené, hogy a GDP visszatérjen a válság előtti potenciális növekedési pályájára, és hogy a válság idején hosszú távon munkanélkülivé vált emberek visszatérhessenek a munkaerőpiacra. Jól horgonyzott, alacsony inflációs várakozások mellett ennek az inflációs költsége elhanyagolható lenne a hosszú távú reálgazdasági nyereséghez képest.

A hiszterézis figyelmen kívül hagyása a költségvetési politika szempontjából is súlyos következménnyel járhat. Fatás-Summers [2016] az Európai Unió tagállamaiban 2010 és 2011 között végrehajtott költségvetési megszorítások hatásait vizsgálva arra a következtetésre jutott, hogy a költségvetési politika által okozott egyszázalékos GDPváltozás várhatóan egyszázalékos, azonos irányú változást okoz a potenciális kibocsátásban is ötéves időhorizonton, tízéves időhorizonton pedig 1,4 százalékost. Tehát a válság alatti költségvetési konszolidációknak nemcsak átmeneti, hanem permanens negatív hatásuk is volt a GDP-re, ezáltal ahelyett, hogy csökkentették volna, csak még tovább növelték a GDP-arányos államadósságot. A hiszterézis figyelmen kívül hagyása ezek szerint túlzott mértékü költségvetési megszorításokat okozott. Mindez azt jelenti, hogy az említett prociklikus beavatkozások helyett a korábbi elképzeléseinkhez képest is nagyobb hangsúlyt kell helyezni az anticiklikus költségvetési politikára.

\section{Tanulságok és a tanulmány motivációja}

A fentiek alapján egyértelmü, hogy a hiszterézis megkerülhetetlen jelensége a gazdaságok müködésének, ami kulcsfontosságú gazdaságpolitikai következményekkel is jár. Ennek ellenére a föáramú közgazdaságtan néhány kivételtől eltekintve nem sok figyelmet fordított rá napjainkig, a rövid és a hosszú távú piaci mechanizmusok szétválasztására épülö új neoklasszikus szintézis gondolatrendszerével pedig egyenesen összeegyeztethetetlen. A heterodox közgazdasági irányzatoktól viszont korántsem idegen a hiszterézis gondolata. A posztkeynesi közgazdászok már a múlt század első felében megfogalmaztak a hiszterézissel összeegyeztethető gondolatokat, és attól kezdve folyamatosan jól illeszkedett a hiszterézis a keresleti oldal dominanciáját hirdető posztkeynesi makroökonómia elméleti keretébe. Ezért a tanulmány amellett érvel, hogy ugyan föáramú közgazdászok munkáiban is többször felbukkant a hiszterézis, jelentősége posztkeynesi szemléletben érthető meg igazán.

Vitathatatlan fontossága ellenére a hiszterézis gyakorlatilag hiányzik a magyar nyelvü közgazdasági szakirodalomból. ${ }^{6}$ Ez a tanulmány ezt az ürt igyekszik betöl-

\footnotetext{
${ }^{5}$ Ismét hozzá kell tenni, hogy a pozitív irányú hiszterézisre vonatkozó empirikus bizonyítékok kevésbé meggyőzők, mint a negatív irányú hiszterézisre vonatkozók.

${ }^{6}$ A Matarka-adatbázis és a vezető hazai közgazdasági szakfolyóiratok keresőmotorjai segítségével rákerestünk a „hiszterézis” kulcsszóra, és mindössze 14 találatot sikerült összegyüjtenünk. Ráadásul ezek közül is hét szakpolitikai dokumentum, tehát csupán a maradék hét tekinthető szakfolyóiratban megjelent tanulmánynak. A hét szakpolitikai dokumentum kivétel nélkül MNB-jelentés. A 2016-os Növekedési jelentés ( $M N B$ [2016]) kivételével ezek csak egy-egy mondat erejéig említik a hiszterézist munkaerőpiaci folyamatok elemzése kapcsán. A hét szakfolyóiratban megjelent tanulmány közül három a Közgazdasági Szemlében, kettő a Hitelintézeti Szemlében, egy a Tér és Társadalomban, egy pedig a Tudásmenedzsmentben jelent meg. Témáját tekintve három tanulmány munkaerőpiaci kérdések
} 
teni: szakirodalmi áttekintést kíván nyújtani a hiszterézis közgazdasági elmélettörténetéről, jelentőségéről és elméleti modelljeiről. A hiszterézis empirikus kimutatásával, mérésével kapcsolatos ökonometriai módszerek egyelöre gyerekcipőben járnak, ráadásul bemutatásuk szemléletmódját tekintve egy egészen más jellegü tanulmányt igényelne, ezért itt terjedelmi okokból legfeljebb egy-egy említés lesz róluk. Nem térünk ki arra sem, hogy milyen problémákat vet fel a hiszterézis az ökonometriai elörejelzések megbízhatóságát illetően, de a jövőben egy újabb tanulmány keretei között igyekszünk majd pótolni a kimaradó ökonometriai részletek ismertetését. Összességében tehát a tanulmány célja, hogy betekintést nyújtson a magyar nyelvü olvasóknak a hiszterézis közgazdasági szakirodalmába, és ösztönözze a hazai közgazdásztársadalmat a témában való elmélyedésre.

A tanulmány hátralévő része a következőképpen épül fel. A hiszterézis közgazdasági elmélettörténetének áttekintése után kifejtjük, hogy miképpen illeszkedik a hiszterézis fogalma a posztkeynesi közgazdaságtan gondolati rendszerébe. Ezután példákkal illusztrálva bemutatjuk a hiszterézismodellek két nagy családját, az egységgyök/nullagyök modelleket, valamint a valódi hiszterézismodelleket. Végül összegezzük a tanulmány főbb megállapításait, és megfogalmazunk néhány következtetést a hiszterézis közgazdasági szakirodalmának várható jövőbeli fejlődéséről.

\section{A hiszterézis helye a közgazdaság-tudományban}

\section{A hiszterézis közgazdasági elmélettörténete}

A hiszterézis görög eredetű szó, jelentése szó szerint: „az, ami később jön”. Általánosságban olyan hatásokat értünk alatta, amelyek azután is fennmaradnak, hogy a kezdeti kiváltó okuk megszünt (Cross [1993]). A kifejezésben felfedezhető a görög

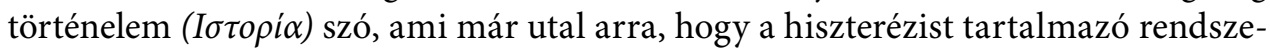
rekben „a történelem számít”, vagyis a rendszer egyensúlyi helyzete nem független a rendszer történelmétől, az általa bejárt úttól. A bevett közgazdasági definíció szerint egy dinamikus gazdasági rendszerben akkor figyelhető meg hiszterézis, ha átmeneti exogén sokkok permanens hatást gyakorolnak a rendszer hosszú távú egyensúlyára ${ }^{7}$ (Amable és szerzőtársai [1993], Göcke [2002]).

Oly sok közgazdasági fogalomhoz hasonlóan a hiszterézis fogalma is a fizikából eredeztethető. Ewing [1881] fedezte fel, hogy amennyiben egy kezdetben semleges

magyarázata kapcsán, kettő a Phillips-görbével kapcsolatos fejtegetések során, egy a 2008-as válság kezelésének nehézségeit illetően, egy pedig a magyar ipar útfüggő területi dinamikájának magyarázatában említi a hiszterézist. Mindegyik tanulmányban csak egy-egy mondatnyi mellékes említést kap a hiszterézis, egyiknek sem központi témája. Tudomásom szerint tehát egyelöre nem létezik olyan magyar nyelvű közgazdasági szakirodalom, amelynek központi témája a hiszterézis lenne.

${ }^{7}$ Itt és a tanulmány hátralévő részében a „hosszú távú egyensúly” kifejezés az „állandósult állapot” szinonimájaként szerepel. Tehát nem a kereslet és a kínálat egyenlőségét (a „rövid távú egyensúlyt”) értjük rajta egy adott piacon: abból önmagában nem következik, hogy a vizsgált dinamikus rendszer releváns változói időben állandók lennének. Ahol nem ad okot félreértésre, ott helyenként jelző nélkül használjuk az „egyensúly” kifejezést: ezekben az esetekben is a hosszú távú egyensúlyt kell érteni rajta. 
töltésű fémnek előbb egy pozitív (negatív), majd egy azzal azonos mértékủ negatív (pozitív) mágneses töltést adunk, akkor a fém nem tér vissza semleges állapotba, hanem marad valamennyi pozitív (negatív) mágneses töltése. A kezdeti mágneses behatás tehát azután is fennmarad a fémben, hogy a kiváltó oka megszünt. Ezt a jelenséget nevezte el Ewing [1881] hiszterézisnek. ${ }^{8}$ A mágneses hiszterézis első matematikai leírása a magyar származású fizikus, Preisach Ferenc nevéhez füződik (Preisach [1935]), azonban ő még specifikusan a mágneses hiszterézis összefüggésében fogalmazta meg modelljét. Évtizedekkel később Krasznoszelszkij-Pokrovszkij [1983], valamint Mayergoyz [1985] fedezték fel, hogy Preisach modellje mögött egy általánosabb matematikai struktúra húzódik meg, ami nem csupán a mágneses hiszterézis vizsgálatára alkalmazható, hanem más, hiszterézissel jellemezhető fizikai, sőt akár fizikán kívüli jelenségek leírására is. A hiszterézis általuk felépített modellje képezi a matematikai alapját a közgazdaságtan következő fejezetben bemutatásra kerülő valódi hiszterézismodelljeinek is.

A közgazdaságtan kutatói közül már Alfred Marshall, Káldor Miklós, Joseph Schumpeter és James Tobin is felvetette a lehetőségét annak, hogy egy gazdasági rendszer egyensúlyon kívüli alkalmazkodási pályája megváltoztatja magát az egyensúlyi helyzetet, amely felé a rendszer tart. Ök azonban még nem használták a hiszterézis kifejezést, és ezek a gondolataik egyébként sem keltettek jelentős tudományos visszhangot. A hiszterézis kifejezés első közgazdasági kontextusú említései Paul Samuelson és Schumpeter egyik tanítványa, Nicholas Georgescu-Roegen nevéhez füződnek, széles körü ismertségre azonban Phelps [1972] munkája által tett szert a fogalom (Cross [1993]). Edmund Phelps az inflációs várakozásokkal bővített Phillipsgörbe bemutatása során kitért annak a lehetőségére, hogy a munkanélküliség természetes rátája függhet a tényleges munkanélküliségi ráta által bejárt pályától, amelyen keresztül eljut a természetes rátához. Ezek szerint már az inflációs várakozásokkal bővített Phillips-görbe egyik „szülőatyja” is számolt a hiszterézis lehetőségével, mégis a pusztán kínálati oldalról meghatározott természetes munkanélküliség koncepciója terjedt el a tudomány fóáramában, ami kizárja a hiszterézist. ${ }^{9}$

Phelps [1972] nyomán a fỏáramú közgazdaságtan képviselői elsőként a tartósan magas munkanélküliség magyarázatában szántak komolyabb szerepet a hiszterézisnek az 1980-as években. A téma felfutása empirikus indíttatású volt: rejtélyként

\footnotetext{
${ }^{8}$ Számos (főként föáramú) közgazdász ennél lazábban használja a hiszterézis kifejezést: akkor is hiszterézisről beszélnek, ha pusztán az történik, hogy egy átmeneti impulzus tartós hatást gyakorol a vizsgált rendszer egyensúlyi állapotára. Tehát már önmagában azt is hiszterézisnek tekintenék, hogy Ewing [1881] kísérletében a kezdeti mágneses impulzus tartós hatást gyakorol a fém mágneses töltésére. Még akkor is annak tekintenék, ha a későbbi ellenirányú impulzus visszaállítaná a kezdeti semleges állapotot. Ewing [1881] és a fizikusok definíciója szerint ez nem lenne hiszterézis. Bővebben lásd az Egységgyök/nullagyök dinamika versus valódi hiszterézis címü alfejezetet. A tanulmány - közgazdasági jellege miatt - a közgazdászok megengedőbb hiszterézisdefinícióját használja.

${ }^{9}$ Igazából az inflációs várakozásokkal bővített Phillips-görbe hagyományos, konstans természetes munkanélküliséget feltételező változatában is jelen van a hiszterézis, csak nem a munkanélküliségi ráta, hanem az infláció dinamikájában nyilvánul meg: egy átmeneti keresleti sokk tartósan megváltoztatja az infláció hosszú távú egyensúlyi értékét. Meglepő, hogy tudomásunk szerint a hiszterézisnek erre a megnyilvánulási formájára még senki sem hívta fel a figyelmet a közgazdasági szakirodalomban.
} 
tekintettek ebben az időben a közgazdászok arra a jelenségre, hogy az 1970-es évek gazdasági megrázkódtatásai (olajársokkok, a termelékenységnövekedés ütemének csökkenése) után az európai munkanélküliségi ráta tartósan magasan maradt, és semmiféle jelét nem mutatta a visszatérésnek az olajválság előtti természetes rátához. Tovább fokozta a rejtélyt, hogy az Egyesült Államokban mindez nem volt megfigyelhető: ugyan ott is megugrott a munkanélküliség, de az átmeneti növekedés után viszonylag gyorsan visszatért a korábbi szintre (Blanchard-Summers [1986], Blanchard [2006]). Az 1970-es évek folyamán még sikerült megmagyarázni különféle kínálatoldali, strukturális tényezőkkel, nominális és reálmerevségekkel, hogy az olajárat és a termelékenységnövekedés ütemét érő átmeneti sokkok miért gyakoroltak meglehetősen perzisztens hatást a munkanélküliség természetes rátájára. A strukturális tényezők között föszerepet kapott például a bértárgyalások centralizáltsága, a szakszervezetek alkuereje, a bérindexálás mértéke, a munkanélkülieknek nyújtott juttatások jellemzői vagy a munkaadók által elvárt és a munkanélküliek által birtokolt képességek közti illeszkedés mértéke. Az 1980-as években azonban továbbra sem csökkent a munkanélküliség, miközben az infláció stabilizálódott. Ez arra utalt, hogy a munkanélküliség természetes rátájának is permanensen magas szinten kellett maradnia. Ekkor viszont az 1970-es évek átmeneti sokkjai közvetlenül nem alakíthatták már a munkanélküliséget, és az említett strukturális tényezőkkel sem lehetett megmagyarázni, hogy miért nem tért vissza a munkanélküliség természetes rátája az olajválság előtti szintre (Cross [1995], Blanchard [2006]). Mivel a kínálatoldali tényezők nem adtak elégséges magyarázatot, ezért joggal merült fel a gondolat, hogy az addigi elképzelésekkel szemben más, akár keresletoldali mechanizmusok is hatással lehetnek a munkanélküliség természetes rátájára, amire ezek által permanens hatást gyakorolhatnak az átmeneti sokkok.

Egy ilyen lehetséges mechanizmus a Blanchard-Summers [1986], [1987] által kidolgozott úgynevezett bennfentes-kívülálló (insider-outsider) munkaerőpiaci mechanizmus, amely hiszterézist produkál a munkanélküliségi rátában. A bennfentes-kívülálló modell alapfeltevése, hogy a béralkuban csak a potenciális munkaerő egy része, egy „bennfentes” csoportja vesz részt. Ez a csoport állhat például a már foglalkoztatott munkavállalókból vagy a szakszervezeti tagokból. Ök a béralku során olyan munkabért követelnek maguknak, amely mellett a munkaadó vállalatok várhatóan foglalkoztatni fogják őket a továbbiakban is. Mivel a munkanélküliekre (a „kívülállókra”) nincsenek tekintettel, a követelt bér magasabb lesz ahhoz képest, ami várhatóan lehetővé tenné a teljes foglalkoztatást. A bérszerződés lejáratáig érkező véletlen sokkokat azonban a béralku során még nem ismerik a munkavállalók, ezért a foglalkoztatás a törekvéseik ellenére is eltérhet minden időszakban a korábbitól. Például egy negatív pénzkínálati sokk esetén a fenti logika alapján megállapított bér mellett a vállalatok kevesebb munkavállalót fognak foglalkoztatni, mint amennyire a bennfentes munkavállalók elözőleg számítottak. Így a következő időszakban már a bennfenteseknek egy szükebb köre fog csak részt venni a béralkuban, akik továbbra is olyan bért fognak követelni maguknak, amely mellett várhatóan ők maradnak a foglalkoztatottak. Ha a sokk átmeneti volt, és nem érkezik újabb, akkor a várakozásaik teljesülnek, így a 
foglalkoztatás egy tartósan alacsonyabb szinten állandósul az átmeneti pénzkínálati sokk elhalása után. ${ }^{10}$

Cross [1987] másképpen magyarázta az 1980-as évek tartósan magas európai munkanélküliségét: ő a phelpsi gondolatot dolgozta ki részletesebben, és megvizsgálta, hogy miként befolyásolja a gazdaság működését, ha egy olyan Phillips-görbét feltételezünk, amelyben a növekvő munkanélküliség egy része „természetessé válik”. Ilyenkor egy átmeneti negatív sokkhatás tartósan megnöveli a természetes rátát, ami a szerző szerint összhangban áll az 1970-es és 1980-as évek európai munkaerőpiaci folyamataival. A tényleges munkanélküliség visszahatását a természetes rátára Phelps [1972] alapján két lehetséges mechanizmussal magyarázta a szerzö.

Egyrészt magasabb foglalkoztatás esetén a munkaerő nagyobb hányada részesül munkahelyi képzésben és profitál a gyakorlat általi tanulásból (learning by doing). A munkanélkülieknél viszont ezek a tapasztalatszerzési lehetőségek elmaradnak, így a magas munkanélküliség kevésbé képzett munkaerőt eredményez. Ráadásul a hoszszú távon munkanélküliek tartósan kikerülhetnek a munkaerőpiacról a képességeik elavulása mellett azért is, mert a hosszú távú munkanélküliség növeli a mentális problémák és a szenvedélybetegségek kialakulásának kockázatát, ezáltal rontja az egyén foglalkoztathatóságát. Egy hosszú munka nélküli időszak pedig önmagában azt jelezheti a munkaadók számára, hogy az illető kevésbé alkalmas a munkavégzésre, ezért számba sem veszik potenciális munkavállalóként.

Másrészt a hiszterézis hátterében állhat az a feltevés is, hogy nagyobb foglalkoztatottság esetén nagyobb a szakszervezeti tagok száma, és ez a szakszervezetek által lefedett és le nem fedett munkahelyek közti bérrés csökkenésével jár együtt. (Hiszen éppen a szakszervezeti bérrés csökkenése teszi lehetővé a nagyobb szakszervezeti foglalkoztatást.) A kisebb szakszervezeti bérrés csökkenti a munkaerőpiaci torzítások mértékét, így csökkenti a munkanélküliség természetes rátáját. Utóbbi mechanizmus mellett nem sok empirikus bizonyíték szól, valószínűbb, hogy inkább a hosszú távú munkanélküliek képességeinek romlása miatt válik a tényleges munkanélküliség „természetessé”.

Ezzel szinte párhuzamosan egy másik empirikus jelenség is hozzájárult a hiszterézis elterjedéséhez a közgazdaság-tudományban. Az amerikai dollár erősödése az 1980-as évek elején az Egyesült Âllamok külkereskedelmi mérlegének jelentős romlásával járt együtt. Az évtized közepére a dollár árfolyama nagyjából viszszatért az 1980-as szint környékére, a külkereskedelmi mérleg passzívuma viszont a várakozásokkal ellentétben változatlanul nagy maradt (Baldwin-Krugman [1989], Dixit [1989]). A hivatkozott tanulmányok szerzői azzal magyarázták a hiszterézist a külkereskedelmi mérlegben, hogy a külföldi vállalatok amerikai piacra történő belépésének van egy jelentős, egyszeri fix költsége, míg a kilépés egyáltalán nem vagy kevésbé költséges. Ennek következtében erősödő dollár mellett újabb és újabb

\footnotetext{
${ }^{10}$ A tartósan magas munkanélküliség bennfentes-kívülálló munkaerőpiaci mechanizmuson alapuló magyarázatának gyengesége, hogy ha a munkanélküliek is gyakorolnak valamekkora (akár nagyon kicsi) hatást a bérmeghatározásra, akkor a hiszterézis megszűnik. Ezért az 1990-es évektől kezdve az elmélet sokat veszített népszerüségéből, helyette a különböző munkaerőpiaci intézmények és makrogazdasági sokkok interakcióin alapuló magyarázatok kerültek a figyelem központjába (Blanchard [2006]).
} 
külföldi vállalatok lépnek be az amerikai piacra, hiszen a hazai devizájukban kifejezve egyre nagyobb bevételre számíthatnak, ami fedezi a belépésük fix költségét. A belépések folyományaként növekszik az import, ami rontja az Egyesült Államok külkereskedelmi mérlegét. Az eredeti szintre visszagyengülő dollár mellett ezek a külföldi vállalatok azonban nincsenek ösztönözve a kilépésre, hiszen a belépés fix költségét már kifizették, így most már gyengébb dollár mellett is képesek nyereségesen müködni. Emiatt a külkereskedelmi mérleg pozíciója tartósan gyengébb marad az átmeneti árfolyamsokk megszünése után is. Dixit [1992] felismerte, hogy a fenti logika általánosabb annál, hogy csak nemzetközi gazdaságtani összefüggésben legyen alkalmazható, és megmutatta, hogy egy tetszőleges tökéletesen versenyzői piacon hiszterézis alakul ki a piaci árat érő átmeneti sokkok következtében, ha a belépéshez kapcsolódik egy egyszeri fix költség.

Delgado [1991] szintén az amerikai külkereskedelmi mérleg 1980 -as évekbeli permanens romlásának idején figyelte meg, hogy az Egyesült Államok piacán értékesítő külföldi vállalatok által szabott árak csak gyengén reagáltak a dollárt érő árfolyamsokkokra: a dollár 1980-as évek eleji felértékelődése során csak kismértékben csökkentek az importált termékek dollárban kifejezett árai, az 1980-as évek második felének leértékelődési időszakában pedig az árak emelkedése volt hasonlóan kis mértékü. Delgado ezt a megfigyelést egy olyan modellel magyarázta, amelyben a vállalatoknak nem a piaci belépéshez, hanem az árváltoztatáshoz kapcsolódóan kell kifizetniük egy fix költséget (az úgynevezett menüköltséget). Ebben az esetben a külföldi vállalatok számára csak akkor éri meg árat csökkenteni, ha a dollár árfolyama jelentős mértékben erősödik. Miután ezt megtették, a dollár fokozatos gyengülésének időszakában a menüköltség elriaszthatja őket az áremeléstől is, így az árak permanensen alacsonyabbak maradhatnak az átmeneti árfolyamsokk elhalása után, tehát hiszterézis alakulhat ki a külföldi vállalatok által szabott árak dinamikájában. Dixit [1991] modelljében szintén a menüköltség jelenléte eredményez hiszterézist egy monopolisztikusan versenyző vállalat termékének áralakulásában, azonban ez a vállalat a belföldi piacon értékesít, így nem a devizaárfolyamot, hanem a piaci árszínvonalat érő átmeneti sokkok relevánsak számára.

Az 1990-es és 2000-es évek folyamán hasonló empirikus rejtélyek hiányában a föáramú közgazdaságtan hiszterézis iránti érdeklődése lankadni kezdett. Az 1980-as évek hiszterézissel kapcsolatos eredményei nem váltak általános érvényűvé, a szakmai közvélemény elkönyvelte, hogy a hiszterézis legfeljebb néhány specifikus jelenség magyarázatában tarthat számot érdeklődésre, főként a munkanélküliség és a nemzetközi kereskedelem elméleteivel kapcsolatban. Az érdeklödés lankadásához az is hozzájárult, hogy a hiszterézissel kapcsolatos legjelentősebb foáramú tanulmányok szerzői (például Olivier Blanchard, Lawrence Summers, Avinash Dixit) nem hangsúlyozták munkásságuk során következetesen a hiszterézis fontosságát, hiszen a fent hivatkozott munkáik után minden átmenet nélkül visszatértek olyan modellek építéséhez, amelyekben független egymástól a kereslet és a kínálat, és az új neoklasszikus szintézis alapelvei érvényesülnek.

A posztkeynesi közgazdászokat viszont ebben az időszakban is aktívan foglalkoztatta a hiszterézis kérdése. Az 1990-es évek első felében több olyan posztkeynesi 
tanulmány is megjelent, amelyek azt igyekeztek tisztázni, hogy az 1980-as években a főáramú közgazdászok által a tartósan magas munkanélküliség magyarázatára kidolgozott modellek valójában nem hiszterézismodellek, mert ezekben a munkanélküliség jellemzően egységgyökfolyamatot követ, amely oly módon, ahogy azokat a fizikusok megfogalmazták, nem tükrözi a hiszteretikus folyamatok számos tulajdonságát (Amable és szerzőtársai [1993], [1994], Cross [1993], [1994], Setterfield [1998]). ${ }^{11}$ A 2000es években néhány szintetizáló jellegű munka is született a posztkeynesiánusok jóvoltából, amelyekben összegyüjtötték a hiszteretikus közgazdasági folyamatok főbb jellemzőit, és leírták a hiszterézismodellek sajátosságait. Továbbra is hangsúlyozták, hogy a „valódi” hiszterézismodellek jóval komplexebb gazdasági dinamikát eredményeznek, mint a diszkrét idejü egységgyökmodellek vagy a folytonos idejü nullagyökmodellek, ezáltal általánosabb érvényüek is (Göcke [2002], Setterfield [2009]).

Szintén a 2000-es években fedezték fel újra a posztkeynesi közgazdászok azt a főként Kaldor [1957] által megalapozott gondolatot, amely szerint a keresleti és a kínálati oldal közötti interakciók útfüggő gazdasági dinamikához, adott esetben hiszterézishez vezethetnek (Arestis-Sawyer [2009]). ${ }^{12}$ Dutt [2006] modelljében például a kibocsátás tényleges növekedési üteme keresleti oldalról, természetes növekedési üteme pedig a modell legegyszerübb változatában kínálati oldalról meghatározott. A kettő közötti eltérés határozza meg a foglalkoztatottsági ráta változását. Ha a központi bank az utóbbira reagálva határozza meg a kamatlábat, hozzáigazíthatja a kibocsátás tényleges növekedési ütemét a természeteshez, ezáltal megvalósulhat a kínálati oldal visszahatása a keresletre: a foglalkoztatottság növekedésére (csökkenésére) válaszul a központi bank kamatot emel (csökkent), így visszafogja (ösztönzi) az aggregált keresletet, közelítve azt az aggregált kínálathoz. Lavoie [2009] megmutatta, hogy egy inflációs célt követő jegybank akkor reagál biztosan kamatemeléssel (csökkentéssel) a foglalkoztatás növekedésére (csökkenésére), ha a hagyományos Phillipsgörbében foglaltakkal ellentétben az infláció nem a munkanélküliség természetes rátától való eltérésére, hanem a munkanélküliség változására reagál. Éppen ez a helyzet a munkanélküliségi hiszterézis modelljeiben, ahol a tényleges munkanélküliségi ráta visszahat a természetes rátára (Phelps [1972], Cross [1987]).

Dutt [2006] modelljében a kereslet is visszahat a kínálatra a posztkeynesiánusok által elöszeretettel használt Kaldor-Verdoorn-törvény mechanizmusán keresztül (Kaldor [1957], Verdoorn [1949]). A törvény pozitív kapcsolatot fejez ki a kibocsátás és a munkatermelékenység növekedési üteme között: a gazdasági növekedés növeli a termelékenységet például a gyakorlat általi tanulás miatt, vagy azért, mert növekvő gazdaságban nagyobb az ösztönzés az innovációra. A kétféle visszacsatolás Dutt [2006] modelljében hiszterézist eredményez: egy átmeneti pozitív (negatív) keresleti sokk tartósan növeli (csökkenti) a gazdasági növekedés ütemét. Hasonló eredményre vezet a Kaldor-Verdoorn-törvény Setterfield [2002], valamint Storm-Naastepad [2012] növekedési modelljeiben is.

\footnotetext{
${ }^{11}$ Az egységgyökfolyamatok és a valódi hiszterézismodellek összevetéséről bővebben lásd a következő fejezetet.

${ }^{12}$ A hiszterézis az útfüggő dinamika egy konkrét típusa. Az útfüggőség és a hiszterézis fogalmának különbségeiről a következő alfejezetben található több információ.
} 
Végül a kereslet-kínálat interakciók posztkeynesi modelljei kapcsán Lavoie [2006] modelljét érdemes még megemlíteni. A szerző az új neoklasszikus szintézis egyszerüsített, háromegyenletes modelljét (ami egy IS egyenletből, egy Phillips-görbéből és egy Taylorszabályból áll) egészítette ki egy negyedik egyenlettel, amely a phelpsi hagyományokat követve azt fejezi ki, hogy a tényleges munkanélküliségi ráta pozitívan visszahat a természetes rátára. Ez a kis változtatás elég ahhoz, hogy hiszterézis alakuljon ki az új neoklaszszikus szintézis modelljében, vagyis egy átmeneti negatív (pozitív) keresleti sokk ne csak rövid, hanem hosszú távon is növelje (csökkentse) a munkanélküliséget.

Évtizedünk közepe felé közeledve a 2008-as világgazdasági válságból történő lassú kilábalás adott új lendületet a hiszterézis közgazdasági szakirodalmának. A téma - a posztkeynesiánusok mellett - újra intenzíven foglalkoztatni kezdte a föáramú közgazdászokat is. Hogy milyen hatalmas felfutása volt az elmúlt néhány évben a hiszterézis empirikus szakirodalmának, arról a bevezető fejezet alapján már képet kaphattunk. A fóáramú elméleti munkák közül pedig elsősorban Galí [2015] modellje érdemel említést. A szerző a közismert újkeynesi makromodellbe (ami alapváltozatában teljesen konzisztens az új neoklasszikus szintézis elméleti megközelítésével) épített be egy bennfentes-kívülálló munkaerőpiaci mechanizmust, felelevenítve Blanchard-Summers [1986] ötletét. Ennek köszönhetően az újkeynesi modellben hiszterézis alakul ki: egy átmeneti keresleti sokk után a változók az eredetihez képest egy tartósan eltérő állandósult állapothoz konvergálnak. A szerző a bennfentes-kívülálló mechanizmussal magyarázta, hogy az Egyesült Államokkal szemben Európában miért nem tűnik stacionernek a munkanélküliségi ráta az 1970-2014-es időszakban: Európában erősebbek a szakszervezetek, így nagyobb a bennfentesek bérmeghatározó ereje.

Érdekes elmélettörténeti kérdés, hogy Galí [2015] modellje mennyire illeszkedik az új neoklasszikus szintézis gondolati rendszerébe. Az alapmodell a szintézis egyik zászlóshajója, és még kibővített formájában is megőrzi annak minden fontos módszertani sajátosságát (optimalizáló reprezentatív szereplők, racionális várakozások, rövid távú nominális merevségek stb.), mégis a sajátos munkaerőpiaci mechanizmusa miatt hiszterézist produkál, amivel éppen az új neoklasszikus szintézis központi gondolatának mond ellent, hiszen a keresleti oldal nemcsak rövid, hanem hosszú távon is befolyásolja a reálváltozók alakulását. Ezzel a reálgazdasági folyamatok kínálatoldali meghatározottságát hirdető újklasszikusok pozíciója olyannyira meggyengül a szintézisen belül, hogy az nem is biztos, hogy képes a továbbiakban az újklasszikusok és az újkeynesiánusok közti konszenzusként funkcionálni.

A válságból való kilábalás a hiszterézis iránt érdeklődő posztkeynesi közgazdászoknak is új lendületet adott. Bassi-Lang [2016] a Kalecki-féle posztkeynesi növekedési modell egy ágensalapú verziójába épített be a beruházási tevékenység beindításához kapcsolódóan egy egyszeri fix költséget, támaszkodva Dixit [1992] piaci be- és kilépési modelljének alapötletére. A fix költség miatt kialakul a kapacitáskihasználtságnak egy belépési és egy kilépési küszöbértéke. ${ }^{13} \mathrm{Ha}$ a kapacitás-

${ }^{13}$ Ez a fix költség nem azonos a beruházási alkalmazkodás modelljeiből (Cooper és szerzötársai [1999], Cooper-Haltiwanger [2006]) ismert nemkonvex alkalmazkodási költséggel. Az egy olyan fix költség, amelyet a vállalatoknak meg kell fizetniük minden periódusban, amelyben beruháznak. A nemkonvex alkalmazkodási költség segít megmagyarázni, hogy a vállalatok miért nem ruháznak be 
kihasználtság a vállalat kilépési küszöbértéke alá csökken, akkor a cég szünetelteti beruházási tevékenységét. Viszont a beruházás megkezdésének fix költsége miatt hiába tér vissza a kapacitáskihasználtság a negatív sokkot megelőző szintre, a vállalat nem biztos, hogy újra beruházásba fog. Csak akkor indul meg újra a beruházás, ha a kapacitáskihasználtság meghaladja a belépési küszöbértéket. A szerzők ezzel a beruházási hiszterézissel magyarázzák, hogy miért nem tért vissza számos gazdaság napjainkig sem a válságot megelőző növekedési pályájára. Néhány, a válság idején kibontakozó makroökonómiai paradoxon mellett a válságkezelés nehézségeire is rávilágít a modell. A gazdaságpolitika nem képes megszüntetni a receszsziót azzal, hogy egy, a válságot kiváltó negatív sokkal megegyező mértékű pozitív keresleti sokkot ad a gazdaságnak: egy ekkora sokk nem elég nagy ahhoz, hogy a vállalatok átlépjék a belépési küszöbüket. Egy nagyobb mértékű sokk viszont elegendő lehet ahhoz, hogy visszatérítse a gazdaságot a válságot megelőző növekedési pályájára.

Egy másik közelmúltbeli posztkeynesi példa Setterfield-Gouri Suresh [2016] modellje. A szerzők a Kalecki-féle növekedési modell egy másik ágensalapú verziójában produkáltak hiszterézist azáltal, hogy feltételezték, hogy a vállalatok folyamatosan felülvizsgálják a hosszú távú növekedési várakozásaikat a kapacitáskihasználtságra vonatkozó rövid távú várakozási hibáik alapján. Ezáltal a hosszú távú egyensúlyi növekedési ráta útfüggővé vált.

Az elmélettörténeti áttekintés végén érdemes egy összegző megjegyzést tenni. Nem helytálló az a vélekedés, amely föként a munkanélküliség természetes rátáját érintő hiszterézis elméletei (Phelps [1972], Cross [1987], Blanchard-Summers [1986], [1987], Gali [2015]) révén terjedt el, és azt állítja, hogy a hiszterézis azáltal áll elö, hogy átmeneti keresleti sokkok permanens hatást gyakorolnak a gazdaság kínálati oldalára. Ez csak egy lehetséges útja a hiszterézis kialakulásának. A piaci be- és kilépés hivatkozott modelljei (Baldwin-Krugman [1989], Dixit [1989], [1992]) például nem specifikálják, hogy a piaci árat (vagy nemzetközi kontextusban a devizaárfolyamot) érő átmeneti sokkok keresleti vagy kínálati eredetűek-e. Utóbbi esetben átmeneti kínálati sokkok gyakorolnak permanens hatást a kínálati oldalra, konkrétan a vállalatok piaci aktivitására. A hivatkozott posztkeynesi modellek (Setterfield [2002], Dutt [2006], StormNaastepad [2012], Bassi-Lang [2016]) hosszú távú egyensúlya pedig az új neoklasszikus szintézis modelljeivel szemben nem kínálati, hanem keresleti oldalról meghatározott, ezért azokban az átmeneti sokkoknak ahhoz, hogy hiszterézis alakuljon ki, nem a kínálatra, hanem az aggregált keresletre kell permanens hatást gyakorolniuk. Ezek a sokkok lehetnek keresleti és kínálati eredetüek is: Bassi-Lang [2016] modelljében például a szakszervezetek alkuerejét érő átmeneti sokkok (mint kínálati sokkok) és a tőkések fogyasztási határhajlandóságát, valamint az optimizmusukat (egészséges életerejüket, az animal spiritset) érintő átmeneti sokkok (mint keresleti sokkok) egyaránt permanens hatást gyakorolnak a gazdaság keresleti oldalról meghatározott egyensúlyi növekedési

hosszú időszakokon keresztül, viszont nem vezet hiszterézishez. A vállalatoknak nem kell megfizetniük a Bassi-Lang [2016] által feltételezett fix költséget minden olyan periódusban, amelyben beruháznak, csupán azokban, amelyekben megkezdik a beruházási tevékenységet az azt megelöző inaktivitás után. A fix költségnek ez a specifikációja már hiszterézishez vezet. 
pályájára a beruházásokhoz kapcsolódó fix költségek jelenlétében. Összegezve: átmeneti keresleti és kínálati sokkok egyaránt vezethetnek hiszterézishez, ha permanens hatást gyakorolnak a gazdaság hosszú távú egyensúlyára, függetlenül attól, hogy az keresleti vagy kínálati oldalról meghatározott.

Végül meg kell jegyezni, hogy az eddig említett példák többsége ugyan makroökonómiai vonatkozású volt, a hiszterézis fogalma időnként felbukkan a közgazdaságtan más területein is. Jó példa erre az új gazdaságföldrajz centrum-periféria modellje (Krugman [1991]), amelyben létezik a szállítási költségnek egy köztes tartománya, ahol a teljes térbeli koncentráció és a gazdasági tevékenységek egyenletes térbeli eloszlása is egyensúlyi lehet, attól függően, hogy a szállítási költség növekvő vagy csökkenő pályán érkezett-e ebbe a tartományba. Tehát az egyensúlyi térszerkezet hiszterézissel jellemezhetö. Ez a tanulmány azonban a hiszterézis fö felbukkanási területére, a makroökonómiára koncentrál.

\section{A hiszterézis helye a posztkeynesi közgazdaságtan gondolati rendszerében}

Az előző alfejezetből kiderült, hogy időnként a főáramú közgazdaságtan érdeklődése is feléled a hiszterézis iránt, amire többnyire a gazdasági dinamika egy speciális eseteként tekintenek. A posztkeynesi közgazdasági elméletben viszont mindig is helye volt a hiszterézishez kötődő gondolatoknak, a posztkeynesiánus elméleti keretben a hiszterézis nem a gazdasági dinamika speciális esete, hanem annak szerves velejárója. Bár maga Keynes explicit módon nem foglalkozott a közgazdasági hiszterézissel, Cross [1993] megjegyzi, hogy a hiszterézis tökéletesen konzisztens Keynes azon nézetével, amely szerint adott exogén tényezők mellett többféle egyensúly is létrejöhet a gazdaságban. Ez az alfejezet amellett érvel, hogy a hiszterézis valódi közgazdasági jelentősége a posztkeynesi közgazdaságtan szemszögéből érthető meg igazán.

A posztkeynesi közgazdasági felfogás egyik alapeleme, hogy a gazdasági szereplök a jövőre vonatkozó döntéseik során nem kockázattal, hanem bizonytalansággal szembesülnek (Knight [1921], Keynes [1921]). Kockázat mellett a szereplők ugyan nem tudják, hogy a jövő lehetséges kimenetelei közül melyik fog bekövetkezni, de azt tudják, hogy melyek a lehetséges kimenetelek, és melyik mekkora valószínüséggel következik be. Bizonytalanság mellett (vagy fundamentális bizonytalanság mellett, ha még inkább hangsúlyozni szeretnénk az eltérést a kockázat megközelítésétől) viszont nem ismertek a bekövetkezési valószínűségek, sőt legtöbbször még a lehetséges kimenetelek sem. ${ }^{14}$ Ebből az következik, hogy a gazdasági szereplők nem tudnak racionális várakozásokat képezni a releváns változók jövőbeli alakulását illetően, és az ökonometriai elörejelzések készítése is komoly nehézségekbe ütközik.

Hogy mi az oka a gazdasági környezetet uraló fundamentális bizonytalanságnak, azzal kapcsolatban két nézet verseng egymással a posztkeynesi szakirodalomban (O’Donnell [2013]).

\footnotetext{
${ }^{14}$ A kockázat és a bizonytalanság fogalmának összevetéséről és a kétféle fogalom elmélettörténetéről kitűnő összefoglalót ad magyar nyelven Bélyácz [2013].
} 


\section{EMBERI KÉPESSÉGEK/JELLEMZŐK FELŐLI MEGKÖZELÍTÉS (Human Abilities/} Characteristics Approach, HAC). Eszerint a gazdasági szereplők nincsenek a szükséges információk és/vagy kognitív képességek birtokában ahhoz, hogy képesek legyenek felmérni a döntésükhöz kapcsolódó összes lehetséges jövőbeli kimenetelt és azok bekövetkezési valószínüségeit. Vagyis a bizonytalanság episztemológiai (ismeretelméleti) eredetü: elvileg lehet, hogy meghatározhatók lennének a jövőbeli kimenetelek és valószínüségeik, de nem vagyunk képesek meghatározni öket (Runde [1990], Meeks [1991], Dosi-Egidi [1991]).

2. ERgodikus/Nem ergodikus MEgKözelítés (Ergodic/Nonergodic Approach, $E N E$ ). Ennek a hívei szerint a múltbeli gazdasági folyamatokból vett minták nem alkalmasak arra, hogy következtetéseket vonjunk le belölük a változók jövőbeli valószínüségeloszlásaira, mert a mögöttes adatgeneráló folyamat állandóan változik. Vagyis a gazdasági idősorok nem ergodikusak: ha végtelen nagy mintánk lenne múltbeli adatokból, még akkor sem tudnánk pontosan meghatározni a folyamat elméleti momentumait. Itt a bizonytalanság ontológiai (lételméleti) eredetü: ha rendelkeznénk is a szükséges információkkal és kognitív képességekkel a változók jövőbeli valószínüségeloszlásainak meghatározásához, az még akkor sem lenne lehetséges (Davidson [1982-83], [1996]). ${ }^{15}$

Lavoie [2014] egyébként megjegyzi, hogy a kétféle megközelítés egyáltalán nem zárja ki egymást, lehet mindkettő egyszerre oka a fundamentális bizonytalanságnak.

A hiszterézis koncepciója az ENE-megközelítéshez köthetö. Felmerül ugyanis a kérdés: mi az oka annak, hogy a gazdasági folyamatok nem ergodikusak? Davidson [19821983], [1996] ezzel kapcsolatban szükszavúan Shackle [1955] nézeteire hivatkozik, amelyek szerint a gazdasági szereplők kritikus döntései változtatják meg az adatgeneráló folyamatot, ezáltal a gazdasági változók valószínűségeloszlását. De mi jellemző ezekre a kritikus döntésekre? Egy lehetséges elképzelés szerint a kritikus döntések útfüggőséget visznek a gazdasági folyamatokba. Az útfüggő folyamatok dinamikáját nem egy egyértelmű egyensúlyi érték irányába terelő visszacsatolás mozgatja, hanem a gazdaság által korábban bejárt út határozza meg a jövőbeli dinamika jellegét. Az útfüggő folyamatok fajtáihoz közelebb juthatunk Kaldor [1934] munkája által, amelyben a gazdasági rendszerek elképzelhető egyensúlyi helyzeteit három csoportba osztotta.

1. Meghatározott (determinate): egy stabil egyensúly létezik, amit exogén sokkok hiányában a gazdaság előbb-utóbb elér, függetlenül attól, hogy milyen úton jut el oda. A legtöbb fóáramú közgazdasági modell egyensúlya meghatározott.

2. Meghatározatlan, meghatározható (definite indeterminate): több stabil egyensúly létezik, amelyek közül az egyikhez konvergál a gazdaság, de hogy pontosan melyikhez, az az egyensúlyhoz vezető út függvénye. Itt tehát a gazdaság dinamikája már útfüggő.

3. Meghatározatlan, meghatározhatatlan (indefinite indeterminate): nincs stabil egyensúly, a gazdaság folyamatos útfüggő mozgásban van.

\footnotetext{
${ }^{15}$ Az ergodikus/nem ergodikus megközelítés lényegéről és elmélettörténetéről színvonalas és kimerítő összefoglalót ad magyar nyelven Bélyácz [2017].
} 
Fontos megjegyezni, hogy a meghatározott egyensúlyú modellekben nincs útfüggőség még akkor sem, ha változóik dinamikája perzisztens. Bár ilyenkor függhet egy változó adott időpontban felvett értéke a korábbi időpontok értékeitől, két megfigyelés közti korreláció nullához tart, ahogy a közöttük eltelt idő tart a végtelenbe. Tehát a változókat érő átmeneti exogén sokkoknak lehet perzisztens hatásuk meghatározott egyensúlyú modellekben is, permanens hatásuk azonban nem: egy idő után „lecsengenek”, így az egyensúly helyzetét és az akörüli ingadozás mértékét nem befolyásolják.

Az egyensúlyi helyzetek Kaldor-féle csoportosítása alapján egyértelmü, hogy az útfüggőségnek több típusa létezik, többféle formában is megjelenhet közgazdasági modellekben. A stabil egyensúly nélküli útfüggő dinamikára klasszikus példát biztosítanak a káoszelmélet közgazdasági alkalmazásai. Rosser [2011] szerint például a gazdasági folyamatok nem ergodicitásának fö oka azok kaotikus jellege, aminek következtében egy kis eltérés a változók induló értékeiben drasztikusan megváltoztatja a gazdaság pályáját. Egyensúlyi jellegü útfüggőséghez vezethetnek a pozitív visszacsatolások, amelyek következtében instabillá válhat egy egyértelmü egyensúlyi helyzet, vagy akár több stabil egyensúly is kialakulhat, és a gazdaság által bejárt úttól függ, hogy melyik funkcionál attraktorként közülük. Ilyen pozitív visszacsatolások képezik a magját a kumulatív okság elméleteinek, amelyekben önmagukat erősítő növekedési folyamatok inferior (nem Pareto-hatékony) egyensúlyi helyzetekben történő bennragadáshoz, régiók közöttti tartós egyenlőtlenségek kialakulásához vezethetnek (Young [1928], Myrdal [1957], Kaldor [1981]). A pozitív viszszacsatolások kitüntetett típusát képezik a növekvő hozadékú folyamatok, amelyek során egy adott tevékenység relatív előnye a többihez viszonyítva annál nagyobb lesz, minél régebb óta vagy minél intenzívebben végzik. Növekvő hozadékú technológiák állnak a technológiai bennragadás (lock-in) elméleteinek középpontjában, amelyekben egy technológia alkalmazásából származó előny a felhasználók számának növekedésével vagy a tanulási hatások miatt az alkalmazás időtartamával nö, így útfüggő módon a gazdaság bennragadhat egy inferior egyensúlyban, amelyben a kevésbé hatékony technológiák használata terjed el (Arthur [1989], Durlauf [1993]). Az úgynevezett nagy lökés (big push) jelenség - Murphy és szerzötársai [1989] által népszerűsített - fejlődés-gazdaságtani modelljében szintén a növekvő hozadékú technológia vezet útfüggő többes egyensúly kialakulásához. Továbbá az új gazdaságföldrajz - Krugman [1991] által felépített - centrum-periféria modelljében is a növekvő hozadékú technológia felelős az útfüggő többes egyensúly kialakulásáért. Előbbiben egy alacsony fejlettségú egyensúlyba ragadhat be a gazdaság egy magas fejlettségü helyett, utóbbiban egy centrum-periféria szituációba ragadhat be a gazdasági tevékenységek egyenletes térbeli eloszlása helyett. Ugyancsak egy növekvő hozadékú folyamat vezet útfüggő többes egyensúly kialakulásához CecchettiKharroubi [2015] már bemutatott modelljében: minél több képzett munkaerőt alkalmaz a pénzügyi vagy a vállalkozói szektor, annál nagyobb bért képes ajánlani, így annál könnyebben tud további képzett munkaeröt felvenni.

A hiszterézis az útfüggőség egy speciális egyensúlyi típusát takarja, amelyben a kialakuló egyensúly nem invariáns a hozzá vezető alkalmazkodási útra, mert az 
alkalmazkodás nemlineáris, közben strukturális változások mennek végbe. Ez nem azonos a többes egyensúly korábban hivatkozott modelljeivel, azokban ugyanis a lehetséges egyensúlyi pozíciók rögzítettek. Hiszterézis esetén egy adott időpontban mindig csak egyetlen egyensúly létezik, de a strukturális változások miatt ez az egyensúly időszakról időszakra változhat. Nem arról van tehát szó, hogy a gazdaságnak eleve adott néhány lehetséges egyensúlyi pozíciója, amelyek közül egyszerre csak egy funkcionál attraktorként, hanem a gazdaság alkalmazkodási pályája folyamatosan formálja a gazdaság dinamikáját aktuálisan meghatározó egyensúlyt (Setterfield [2009]).

A hiszterézis tehát azáltal illeszkedik szervesen a posztkeynesi közgazdasági elméletbe, hogy az útfüggő gazdasági dinamika egyik legfontosabb típusaként egy lehetséges magyarázattal szolgál arra a kérdésre, hogy miért nem ergodikusak a gazdasági folyamatok. A nem ergodicitás egyik lehetséges okaként pedig megalapozza azt a fundamentálisan bizonytalan döntési környezetet, amelybe a posztkeynesi közgazdászok a modelljeiket helyezik. Ezzel szemben a fóáramú közgazdaságtan modelljei az ergodikus hipotézis alapján állnak (Bélyácz [2017]), logikus tehát, hogy azokban a hiszterézis legfeljebb a gazdasági dinamika egyfajta kirívó, speciális eseteként képes megjelenni.

\section{A hiszterézis közgazdasági modelljei}

\section{Egységgyök/nullagyök modellek}

Az elmélettörténeti áttekintés után felmerülhet a kérdés, hogy miként modellezhetünk hiszteretikus gazdasági folyamatokat. Az előző fejezetben hivatkozott hiszterézismodellek mindegyike besorolható két modellcsalád közül valamelyikbe: vagy egységgyök/nullagyök modellről, vagy „valódi” hiszterézismodellről beszélhetünk. Elsőként az egyszerűbb és közismertebb egységgyök/nullagyök modelleket mutatjuk be, majd áttérünk a valódi hiszterézismodellek ismertetésére.

A diszkrét idejü dinamikus modelleket rendszerint differenciaegyenletek, többváltozós esetben differenciaegyenlet-rendszerek formájában írjuk fel az endogén változók szintjére vonatkozóan. Közismert, hogy amennyiben az ilyen rendszerek együtthatómátrixának létezik 1-gyel egyenlö sajátértéke, vagyis a rendszernek egységgyöke van, akkor a modell hosszú távú egyensúlya nem egyértelmüen meghatározott, sztochasztikus esetben pedig a modell endogén változói nem stacionáriusak (Hamilton [1994]). Folytonos idejü dinamikus rendszerek esetében ennek a helyzetnek az felel meg, amikor a rendszer együtthatómátrixának (a Jacobi-mátrixnak) létezik 0-val egyenlö sajátértéke, vagyis nullagyöke van. A folytonos idejü dinamikus modelleket ugyanis differenciálegyenletek, többváltozós esetben differenciálegyenlet-rendszerek formájában szokás felírni, amelyek nem az endogén változók szintjére, hanem az időbeli változásukra (idő szerinti deriváltjukra) vonatkoznak.

Ezek az egységgyök/nullagyök modellek képesek megragadni a hiszteretikus gazdasági dinamika néhány fontos jellegzetességét. Tekintsük - Cross [1993] példáját követve - az (1) egyváltozós, diszkrét idejü folyamatot: 
$X_{t}=\alpha+\beta X_{t-1}+Z_{t}$

ahol $X_{t}$ a modell endogén változója, $Z_{t}$ pedig az exogén változója, ami lehet sztochasztikus és determinisztikus is. $Z_{t}$ legtöbbször egy független, azonosan normális eloszlású véletlen változó szokott lenni 0 várható értékkel és konstans varianciával. Az $\alpha$ és a $\beta$ pedig valós paraméterek, ahol $-1<\beta \leq 1$.

Állandósult állapotban (amire itt az egyensúly szinonimájaként tekinthetünk) minden változó értéke időben állandó. Ezt kihasználva könnyen kiszámíthatjuk az (1) egyenletből $X$ egyensúlyi értékét:

$\bar{X}=\frac{\alpha+\bar{Z}}{1-\beta}$,

ahol a változók egyensúlyi értékeit felülvonással jelöljük.

Ha $\beta \neq 1$, akkor $X$ egyensúlyi értéke egyértelműen meghatározott, ha pedig $-1<\beta<1$, akkor stabil is (Hamilton [1994]). Ilyenkor tehát hiszterézis fel sem merülhet. Ha viszont $\beta=1$, vagyis $X$ egységgyökfolyamatot követ, akkor a (2) kifejezés nem értelmezhető, tehát az egyensúly determinálatlan: $X$-nek végtelen sok lehetséges egyensúlyi értéke létezik. Giavazzi-Wyplosz [1985] azonban rámutatott, hogy ez a determinálatlanság csak látszólagos, ugyanis egy egységgyök/nullagyök folyamat kezdő értékének, valamint alkalmazkodási paramétereinek ismeretében egyértelmüen meghatározható, hogy a végtelen sok lehetséges egyensúlyi értéke közül további exogén változások hiányában melyikre fog beállni. ${ }^{16}$ Ilyenkor csak a korábban bejárt út ismeretében tudjuk meghatározni a folyamat értékét egy adott periódusban, vagyis az endogén változók egyensúlyi értéke útfüggő. Ez jól látszik, ha az (1) egyenletet viszszafelé iteráljuk, feltéve, hogy $\beta=1$ :

$X_{t}=X_{0}+\alpha t+\sum_{i=0}^{t} Z_{t-i}$

A (3) egyenletből világosan látszik, hogy a $Z$ exogén változó összes múltbeli értéke egyforma súllyal befolyásolja az $X$ endogén változó mai értékét. Ez azt jelenti, hogy amennyiben egy átmeneti exogén sokk éri $Z$-t, $X$ nem tér vissza az eredeti egyensúlyi pályájára a sokk elhalása után sem, hanem egy, a korábbitól tartósan eltérő egyensúlyi pályára áll rá. Ezzel $X$ megfelel a hiszteretikus folyamatok legfontosabb definiáló tulajdonságának: egy átmeneti exogén sokk permanens hatást gyakorol az egyensúlyára.

Setterfield [2009] példáját követve a többváltozós egységgyök/nullagyök modelleket Lavoie [2006] modelljén keresztül mutatom be, ami folytonos idejü, tehát nullagyökmodell. A szerző az új neoklasszikus szintézis egyszerüsített, háromegyenletes alapmodelljébe vezetett be egy visszacsatolást a tényleges és a természetes munkanélküliség között, és megmutatta, hogy ez a kis módosítás elég ahhoz, hogy az új neoklasszikus szintézis modelljében hiszterézis alakuljon ki. A modell egyenletei a következők:

${ }^{16}$ Giavazzi-Wyplosz [1985] megállapítása többváltozós egységgyök/nullagyök modellek esetében is érvényes. 
$\dot{\pi}=-\alpha\left(U-U_{n}\right)$,

$U=\beta+\varphi r$,

$r=r_{n}+\delta\left(\pi-\pi^{T}\right)$,

$\dot{U}_{n}=\eta\left(U-U_{n}\right)$,

ahol $\pi$ az infláció, $\pi^{T}$ a jegybank inflációs célja, $U$ a tényleges munkanélküliségi ráta, $U_{n}$ a munkanélküliség természetes rátája, $r$ a reálkamatláb, $r_{n}=\left(U_{n}-\beta\right) / \varphi$ pedig a természetes reálkamatláb, amely mellett sokkok hiányában és az inflációs cél elérése esetén a munkanélküliség a természetes rátájára áll be. $\mathrm{Az} \alpha, \beta, \delta, \varphi$ és $\eta$ pozitív paraméterek, a változók fölé írt pont pedig az idő szerinti deriváltjukra utal.

A $\alpha$ megmutatja, hogy az infláció mennyire erősen reagál a munkanélküliség természetes rátától való eltérésére. $\mathrm{A} \beta$ a munkanélküliségi rátának az a szintje, amely nulla reálkamatláb mellett állna be. A $\delta$ meghatározza, hogy a jegybank mennyire erős kamatreakciót ad az inflációnak a célértékétől vett eltérésére. A $\varphi$ megmutatja, hogy a munkanélküliségi ráta mennyire erősen reagál a reálkamatláb változásaira. $\mathrm{Az} \eta$ pedig a hiszterézis erősségét meghatározó paraméter, ugyanis azt mutatja meg, hogy a munkanélküliség természetes rátája milyen mértékben változik a tényleges és a természetes munkanélküliség eltérésének következtében.

A (4) egyenlet a Phillips-görbe az infláció változására felírva. ${ }^{17} \mathrm{Az}$ (5) egyenlet az IS összefüggés, a (6) egyenlet pedig a jegybank által követett Taylor-szabály. A standard modellhez képest a (7) egyenlet jelenti az újdonságot, amely kifejezi, hogy a munkanélküliség természetes rátája növekszik, ha a tényleges munkanélküliség nagyobb nála, fordított esetben csökken.

A (4), (5) és (6) egyenletek kombinálása, valamint egy idő szerinti totális deriválás után az alábbi összefüggéshez jutunk:

$\dot{U}_{n}=-(\alpha \varphi \delta-\eta)\left(U-U_{n}\right)$.

A (8) egyenlet a (7) egyenlettel kiegészülve egy kétváltozós differenciálegyenlet-rendszert alkot, amely akkor kerül egyensúlyba, ha $\dot{U}=\dot{U}_{n}=0$. Ez akkor és csak akkor teljesül, ha $U=U_{n}$. Első ránézésre nincs abban semmi újdonság, hogy egyensúlyban a munkanélküliség beáll a természetes rátájára, de ne feledjük, hogy most a természetes ráta is változik, ezért az $U=U_{n}$ egyensúlyi feltétellel a tényleges és a természetes munkanélküliség végtelen sok kombinációja konzisztens. Ezeket a 2. ábrán a 45 fokos egyenes képviseli, amely mind a tényleges, mind a természetes munkanélküliség nyugalmi vonalaként szolgál.

Tegyük fel, hogy $\alpha \varphi \delta>\eta$, vagyis a hiszterézis nem túlzottan erős. ${ }^{18}$ Azt is tegyük fel, hogy kezdetben az $A$ egyensúlyi pontban van a gazdaság, majd egy átmeneti negatív

\footnotetext{
${ }^{17}$ A Phillips-görbének ez a felírása gyakorlatilag egy egyszerű adaptív szabályt feltételez az inflációs várakozások kialakítására vonatkozóan: a várt infláció megegyezik az előző időpont inflációs rátájával.

${ }^{18}$ Ellenkező esetben módosulna a 2. ábrán feltüntetett dinamika (a $C$ pontban még nagyobb lenne a munkanélküliség, mint a $B$ pontban), de a hiszterézis megmaradna, és az egyensúlyi pontok is stabilak maradnának. A stabilitás fennmaradását jelzi, hogy a (9) differenciálegyenlet-rendszer Jacobimátrixának egyik sajátértéke mindenképp negatív, és a másik sem pozitív.
} 
2. ábra

Nullagyök-hiszterézis az új neoklasszikus szintézis modelljében változó természetes munkanélküliség mellett

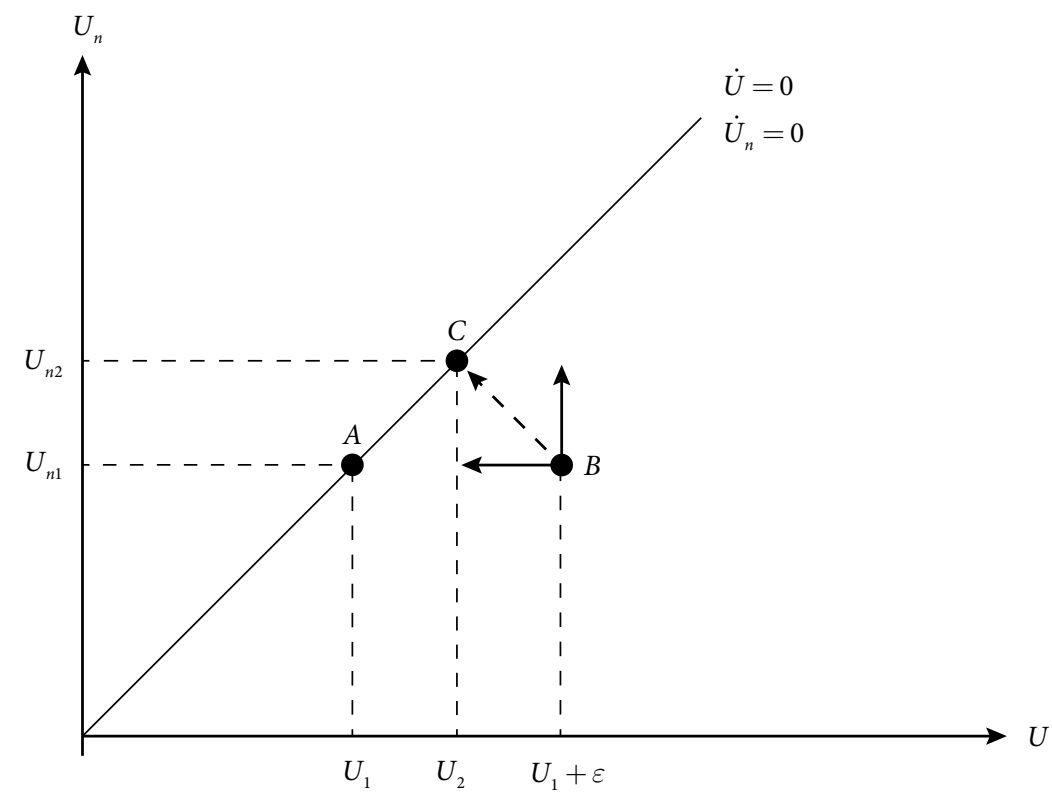

Forrás: saját szerkesztés Setterfield [2009] alapján.

keresleti sokk következtében a munkanélküliség az $U_{1}+\varepsilon$ értékre növekszik. Ekkor a munkanélküliség természetes rátája még változatlanul $U_{n 1}$, tehát a sokk a $B$ pontba löki a gazdaságot. A sokk elhalásával egyrészt a tényleges munkanélküliség kezd visszatérni a természetes rátához a (8) egyenlet értelmében, másrészt a természetes ráta is közelít a tényleges munkanélküliséghez a (7) egyenletnek megfelelően. Így előbb-utóbb beáll egy egyensúly, ahol a tényleges és a természetes munkanélküliség egyenlö, de ez nem az eredeti $A$ egyensúlyi pont lesz, hanem egy új, $C$ egyensúlyi pont. Látható, hogy az átmeneti sokk után a munkanélküliség valamelyest visszatért a kezdő értéke irányába, de nem teljesen: az eredetihez képest egy tartósan magasabb egyensúlyi értékre állt be, vagyis hiszterézis figyelhető meg. A jelenség oka az, hogy a megnövekedett munkanélküliség egy része „természetessé vált”, vagyis az egyensúlyon kívüli alkalmazkodás során a munkanélküliség természetes rátája is nagyobb lett.

A nullagyök-hiszterézis jelenléte a modellben algebrailag is könnyen azonosítható. Írjuk fel a (7) és a (8) egyenletekből álló differenciálegyenlet-rendszert mátrix alakban!

$\left[\begin{array}{c}\dot{U} \\ \dot{U}_{n}\end{array}\right]=\left[\begin{array}{cc}-(\alpha \varphi \delta-\eta) & \alpha \varphi \delta-\eta \\ \eta & -\eta\end{array}\right]\left[\begin{array}{c}U \\ U_{n}\end{array}\right]$.

A (9) differenciálegyenlet-rendszer Jacobi-mátrixának sajátértékei:

$\lambda_{1}=0, \quad \lambda_{2}=-\alpha \varphi \delta$. 
Látható, hogy az egyik sajátérték 0 , vagyis a dinamikus rendszernek nullagyöke van. Erről kapták a nevüket a nullagyökmodellek, ugyanis általában is igaz, hogy ha egy lineáris dinamikus modellben nullagyököt találunk, akkor az hiszterézist produkál.

Az előző fejezetben hivatkozott modellek közül az egységgyök/nullagyök modellek családjába sorolhatjuk egyrészt azokat, amelyek Lavoie [2006] bemutatott modelljéhez hasonlóan egy olyan Phillips-görbét feltételeznek, amelyben müködik pozitív visszacsatolás a tényleges munkanélküliség felől a természetes irányába, ezáltal hoszszú távon is átváltás alakul ki az infláció és a munkanélküliség között (Phelps [1972], Cross [1987]). Másrészt idetartoznak a más jellegü kereslet-kínálat interakciókat tartalmazó modellek (Dutt [2006], Storm-Naastepad [2012]), harmadrészt pedig a bennfentes-kívülálló munkaerőpiaci mechanizmust tartalmazó modellek is (BlanchardSummers [1986], [1987], Galí [2015]).

\section{Valódi hiszterézismodellek}

Számos posztkeynesi közgazdász szerint az egységgyök/nullagyök modellek valójában nem tekinthetők hiszterézismodelleknek, ugyanis matematikai struktúrájukat tekintve nincs sok közük a fizikusok által megalkotott hiszterézismodellekhez (Amable és szerzötársai [1993], [1994], Cross [1993], Setterfield [1998], [2009]). Ebből adódóan a hiszteretikus folyamatok számos fontos tulajdonságát képtelenek reprodukálni, sokkal kevésbé komplex útfüggő dinamika alakul ki bennük, mint a „valódi” (true) hiszterézismodellekben. ${ }^{19}$

A valódi hiszterézis hátterében az úgynevezett hiszterézisoperátor áll, amelynek matematikai struktúráját Krasznoszelszkij-Pokrovszkij [1983], valamint Mayergoyz [1985] dolgozta ki. A 3. ábra a legegyszerübb formájában Cross [1993] és Göcke [2002] munkái alapján mutatja be a hiszterézisoperátort, amelynek $x$ az inputváltozója, $y$ az outputváltozója, $a$ és $b$ pedig $x$ két küszöbértéke, amelyek átlépése strukturális változást generál. Az $y$-ról feltesszük, hogy egy kétértékủ változó. Ha $x<a$, akkor $y=0$, ha $x>b$, akkor $y=1$. Ha viszont $x \in[a, b]$, akkor $y$ a 0 és az 1 értéket is felveheti. Amennyiben $x$ csökkenő pályán érkezett meg az $[a, b]$ intervallumba, akkor $y=1$. Ha növekvő pályán érkezett, akkor viszont $y=0$. Tehát amennyiben $x$ az $[a, b]$ intervallumba esik, $y$ értéke nem változik az előző időszakhoz képest. Ezért az $[a, b]$ intervallumot inaktivitási tartománynak nevezzük. Ezen a tartományon belül $y$-nak két egyensúlyi értéke is elképzelhető, de egy adott időszakon belül az egyensúly egyértelmủen meghatározott azáltal, hogy $x$ melyik irányból érkezett meg az inaktivitási tartományba.

Egy egyszerü közgazdasági példa szemléletesen megvilágítja a hiszterézisoperátor müködését. Tegyük fel, hogy a 3. ábra Dixit [1992] modelljének szellemében egy tökéletesen versenyző vállalat piacra történő be- és kilépési döntését szemlélteti. Legyen $x$ a vállalat számára exogén piaci ár, valamint $y=1$, ha a vállalat aktív a piacon, és $y=0$, ha a vállalat nem aktív a piacon. Tegyük fel, hogy a piacra történő belépésnek

\footnotetext{
${ }^{19}$ A valódi hiszterézismodell kifejezést Setterfield [2009] munkájából kölcsönöztük.
} 
3. ábra

A hiszterézisoperátor

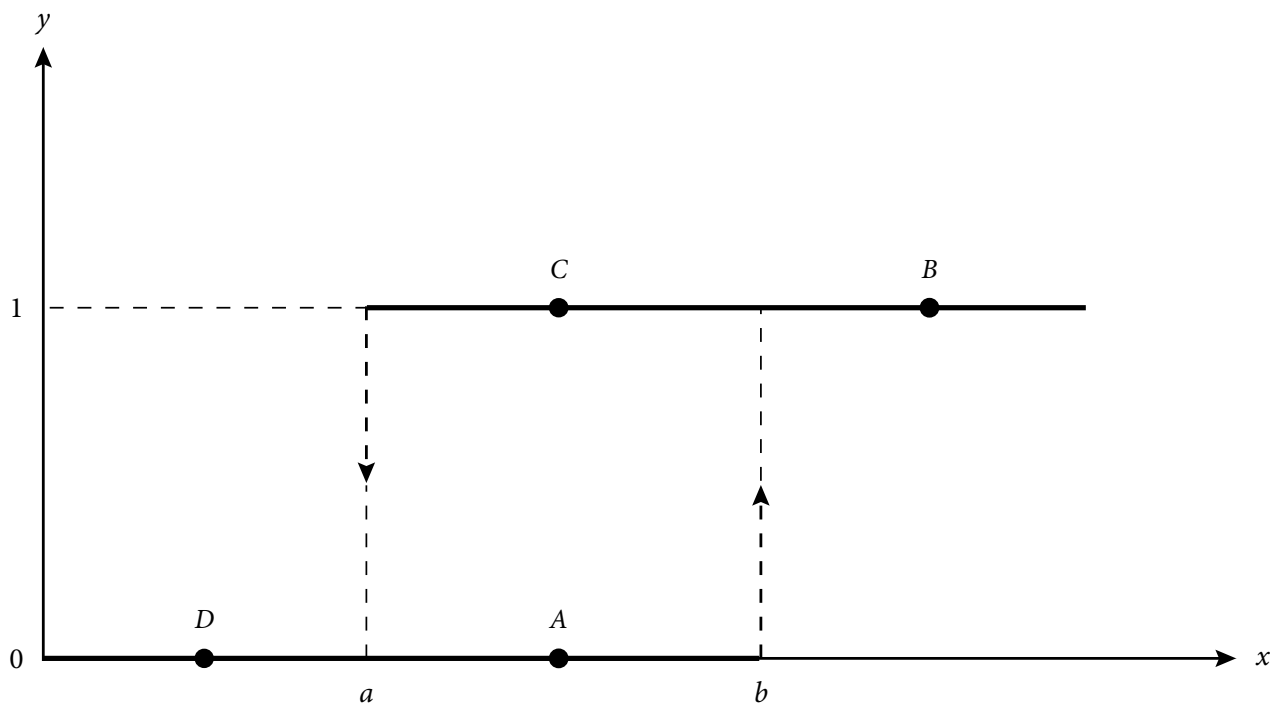

Forrás: saját szerkesztés Cross [1993] és Göcke [2002] alapján.

van egy egyszeri fix költsége. ${ }^{20}$ Ekkor $a$ a vállalat átlagos változó költségével egyenlo, $b$ pedig az átlagos változó és az átlagos fix költségének összegével. Tegyük fel azt is, hogy az $A$ pontban vagyunk az inaktivitási tartományon belül, és a vállalat kezdetben nem aktív. Ekkor az ár ugyan meghaladja az átlagos változó költséget, a vállalat mégsem lép be a piacra, mert a fix költség felemésztené a nyereségét. Ha viszont az ár átlépi a $b$ küszöbértéket, akkor már fedezi a fix költséget is, ezért a vállalat belép a piacra, és átkerülünk a $B$ pontba. Ezek után tegyük fel, hogy az ár visszacsökken az induló értékére, így a $C$ pontba kerülünk: a vállalat továbbra is aktív marad, mert az ár meghaladja az átlagos változó költséget, a fix költséget pedig már úgyis kifizette. Látható, hogy az inputváltozó visszatért az induló értékére, az outputváltozó mégis a korábbitól eltérő egyensúlyi értékre állt be, vagyis az egyensúly útfüggő módon alakult ki. Természetesen ez nem jelenti azt, hogy a vállalat örökké a piacon marad: ha az ár az a küszöbérték alá csökken, akkor már nem fedezi az átlagos változó költséget sem, ezért a vállalat kilép a piacról, és a $D$ pontba kerülünk.

A valódi hiszterézissel jellemezhető folyamatok három kulcsfontosságú tulajdonságát emelhetjük ki (Amable és szerzőtársai [1993], [1994], Göcke [2002], Setterfield [2009]).

1. Irreverzibilitás/remanencia: az első tulajdonság kétféle megnevezése ugyanazt a jelenséget takarja - eltérő hangsúlyokkal megfogalmazva. Az irreverzibilitás azt jelenti,

${ }^{20}$ Ismételten hangsúlyozni kell, hogy ez a fix költség nem ugyanolyan jellegű, mint a beruházási alkalmazkodás modelljeiben megszokott nemkonvex alkalmazkodási költség. Bővebben lásd a 13. lábjegyzetet. 
hogy egy átmeneti sokk után a rendszer nem feltétlenül tér vissza az induló egyensúlyába, hanem egy másikhoz tart. A remanencia pedig leginkább „fennmaradásként” fordítható magyarra, és arra utal, hogy egy átmeneti sokk hatása nem tünik el a rendszerből az elhalása után, hanem hosszú távon „fennmarad”. Ezt a tulajdonságot már nyomon követtük a 3. ábrán: láttuk, hogy az $A$ egyensúlyi pontból kiindulva egy $x$-et érö átmeneti sokk után nem az $A$, hanem a $C$ egyensúlyi helyzet áll be.

2. Szuperreverzibilitás hiánya: ez még az irreverzibilitásnál is erősebb tulajdonság, és azt a jelenséget takarja, hogy amennyiben egy átmeneti sokk után beálló új egyensúlyban egy újabb átmeneti sokk éri a rendszert, amely az elözővel azonos abszolút értékü, de ellentétes elöjelü, akkor sem tér vissza a rendszer az induló egyensúlyba. ${ }^{21} \mathrm{~A}$ 3. ábrán például elképzelhetünk egy olyan szituációt, amikor az $A, B$ és $C$ pontok viszonylag közel helyezkednek el a $b$ küszöbértékhez. Ha ebben a helyzetben az $A$ egyensúlyból kiindulva egy átmeneti pozitív sokkot adunk $x$-nek, akkor annak elhalása után $y$ szokás szerint a $C$ egyensúlyba áll be. Ha viszont a $C$ egyensúlyi pontban egy újabb átmeneti sokkot adunk $x$-nek, amely az elözővel azonos abszolút értékü, de negatív, akkor az nem lesz elég nagy ahhoz, hogy $x$ az $a$ küszöbérték alá csökkenjen, ezért ennek a sokknak nem lesz útfüggő hatása: a lecsengése után a $C$ pontba tér vissza y. Tehát az ellentétes előjelü sokk hatására sem áll vissza az $A$-val jelölt egyensúly.

3. Szelektív memória: a harmadik tulajdonság arra utal, hogy nincs végletes útfüggöség, a múltbeli sokkok közül nem mindegyik befolyásolja a rendszer aktuális állapotát és dinamikáját. Ha például a 3. ábrán az $A$ egyensúlyi pontból kiindulva egy viszonylag kicsi átmeneti sokk éri az $x$ inputváltozót, ami nem eredményez küszöbérték-átlépést, akkor az $y$ outputváltozó a sokk elhalása után visszatér az $A$ egyensúlyba. Ilyenkor tehát nincs útfüggő hatása az átmeneti sokknak, amely ezzel törlődik a rendszer memóriájából. Elegendően nagy, küszöbérték-átlépést eredményező pozitív sokk után viszont $y$ a $C$ egyensúlyba áll be a sokk lecsengése után, aminek így útfüggő hatása van, és a rendszer hosszú távon is „emlékszik” rá. A valódi hiszteretikus folyamatok memóriája tehát szelektív: a kis sokkok nem maradnak meg a rendszer memóriájában, a nagy sokkok viszont igen.

Az előző fejezetben hivatkozott modellek közül azokban találkozhatunk valódi hiszterézissel, amelyekben a sokkokhoz történő alkalmazkodás valamilyen fix költséggel jár, a fix költség jelenléte pedig alkalmazkodási küszöbértékek kialakulásához vezet. A fix költség kapcsolódhat például a hazai piacra történő belépéshez (Dixit [1992]), a külpiacokra történő belépéshez (Baldwin-Krugman [1989], Dixit [1989]), a beruházási tevékenység megkezdéséhez (Bassi-Lang [2016]) vagy az árváltoztatáshoz. Utóbbi esetben a fix költséget menüköltségnek szokás nevezni (Delgado [1991], Dixit [1991]).

Érdemes a valódi hiszterézismodellek két további példáját megemlíteni, amelyekről eddig nem esett szó a tanulmányban. Szintén valamiféle fix költség jelenléte

\footnotetext{
${ }^{21}$ Ugyanakkor az előzőnél nagyobb abszolút értékủ sokk visszaállíthatja az induló egyensúlyt. A szuperreverzibilitás hiánya tehát nem mond ellent Okun [1973] és Ball [2015] gondolatainak a magas nyomású gazdasággal kapcsolatban. A gazdaságpolitika továbbra is képes lehet egy elegendően nagy méretủ átmeneti pozitív keresleti sokkal semlegesíteni egy átmeneti negatív sokk permanens hatását, csak még nagyobb sokkra, még „magasabb nyomásra” van szükség, mint szuperreverzibilitás jelenlétében.
} 
eredményez valódi hiszterézist Cross [1994] eszközválasztási modelljében. Ebben a gazdasági szereplőknek döntést kell hozniuk, hogy a vagyonukat hazai vagy külföldi devizában denominált betétben tartsák-e. A kétféle eszköz közötti váltásnak van egy egyszeri fix költsége, amely tranzakciós és döntési költségből áll össze. A fix költség következtében megjelenik a hazai kamatlábnak egy felső küszöbértéke, amelynek átlépése esetén érdemes külföldiröl hazai devizában denominált betétre váltani, valamint egy alsó küszöbértéke, amelynek átlépése esetén a gazdasági szereplö hazairól külföldi devizában denominált betétre vált. Ha a hazai kamatláb a két küszöbérték közötti tartományba kerül, akkor ismernünk kell a kamatlábmozgások történetét ahhoz, hogy meg tudjuk állapítani, hogy a gazdasági szereplő melyik eszközben tartja a vagyonát.

Nincs szükség fix költségek feltételezésére ahhoz, hogy valódi hiszterézis alakuljon ki Setterfield [2002] modelljében. A szerző Kaldor [1981] kumulatív oksági modelljében azzal próbálta orvosolni a „túlzott kumuláció” problémáját, hogy nemlinearitást vezetett be a Kaldor-Verdoorn-törvénybe: feltételezte, hogy amennyiben a kibocsátás meghalad egy küszöbértéket, a Verdoorn-együttható csökken, vagyis a gazdaság kevésbé képes a kibocsátás növekedését termelékenységnövekedéssé konvertálni a technológiai bennragadás miatt. Ezáltal a Kaldor-Verdoorn-törvényben rejlő alapvető pozitív visszacsatolást kiegészítette egy negatív visszacsatolással, ami valamelyest korlátozza a kumulatív okság mechanizmusát. A küszöbérték bevezetése pedig valódi hiszterézist eredményez a kibocsátásban.

Látható, hogy nemcsak posztkeynesi, hanem föáramú közgazdászok munkáiban is találkozhatunk valódi hiszterézissel. A kutatók két csoportja között abban rejlik az egyik legfőbb különbség, hogy a fóáramú közgazdászok jellemzően a gazdasági szereplők dinamikusan optimalizáló magatartásából vezetik le az alkalmazkodási küszöbértékeket (Dixit [1989], [1991], [1992], Delgado [1991]), a posztkeynesiánusok viszont a fundamentális bizonytalanság és a korlátozottan racionális gazdasági szereplők feltevéseire alapozva nem támasztanak ilyen igényt. Helyette az alkalmazkodási folyamat sajátosságai alapján érvelnek amellett, hogy korlátozottan racionális viselkedés mellett is (sőt különösen amellett) léteznie kell bizonyos alkalmazkodási küszöbértékeknek (Cross [1994], Setterfield [2002], Bassi-Lang [2016]).

\section{Egységgyök/nullagyök dinamika versus valódi hiszterézis}

Számos posztkeynesi közgazdász szerint csak a valódi hiszterézismodellek által produkált útfüggő dinamika tekinthető hiszterézisnek, az egységgyök/nullagyök modellekben megfigyelhetö nem (Amable és szerzötársai [1993], [1994], Cross [1993], [1994], Göcke [2002], Setterfield [1998], [2009]). Leginkább azért nem, mert matematikai struktúrájuknak nincs köze a hiszterézis fizikusok által felépített modelljeihez (Krasznoszelszkij-Pokrovszkij [1983], Mayergoyz [1985]). Ebből adódóan az egységgyök/nullagyök modellek által produkált útfüggő dinamika nem tükröz a valódi hiszterézis előző alfejezetben ismertetett három tulajdonsága közül kettőt, és a harmadikat is csak látszólag tükrözi. 
Az egységgyök/nullagyök folyamatok szuperreverzibilisek: bár egy átmeneti sokk után egy tartósan eltérő egyensúlyi értékre állnak be az eredetihez képest, de ha ebben az új egyensúlyban egy, az előzővel azonos abszolút értékủ, ellentétes előjelü sokk éri őket, akkor visszatérnek az induló egyensúlyba. Ez a tulajdonság abból fakad, hogy a valódi hiszterézismodellekkel ellentétben az egységgyök/nullagyök modellek lineárisak. Egy átmeneti sokk nem okoz strukturális változást a modellben, csupán szélsőségesen perzisztens hatást gyakorol az endogén változóira.

További egyértelmủ különbség a valódi hiszterézismodellekhez képest az, hogy az egységgyök/nullagyök folyamatok memóriája nem szelektív, hanem teljes: a (3) egyenletből világosan látszik, hogy egy egyváltozós egységgyökfolyamat az összes múltbeli exogén sokk értékére egyforma súllyal „emlékszik”. Ez többváltozós esetben és folytonos idejü nullagyökfolyamatok esetében is igaz. Ehhez képest az elöző alfejezetben láttuk, hogy valódi hiszterézis esetén azok a sokkok előbb-utóbb eltűnnek a rendszer memóriájából, amelyek nem generáltak küszöbérték-átlépést. ${ }^{22}$

Egy közös tulajdonsága látszólag van az egységgyök/nullagyök folyamatoknak és a valódi hiszteretikus folyamatoknak: egy átmeneti sokk után egyik sem tér vissza feltétlenül az induló egyensúlyba, hanem tartósan beállhatnak egy új egyensúlyi értékre. Azonban az egységgyök/nullagyök modellekben az irreverzibilitás perzisztenciaként jelenik meg, a valódi hiszterézismodellekben viszont remanenciaként. Vagyis az egységgyök/nullagyök folyamatok csak azért irreverzibilisek, mert extrém mértékben perzisztensek, aminek következtében egy átmeneti sokk hatása sosem „cseng le” az endogén változóban. A valódi hiszteretikus folyamatok irreverzibilitása viszont nem egy szélsőségesen nagyfokú perzisztenciából fakad, hanem abból, hogy bizonyos átmeneti sokkok strukturális változást generálnak a modellben. A sokk következtében tulajdonképpen egy új modellstruktúra lép érvénybe a korábbiakhoz képest, egy új egyensúly kezd el a folyamat attraktoraként funkcionálni, ami addig nem is létezett. (Például a 3. ábrán ez úgy jelenik meg, hogy a rendszer átlép a hiszterézisoperátor egyik ágáról a másikra.) Nem azért lesz tehát permanens hatásuk az átmeneti sokkoknak, mert a folyamat extrém mértékben perzisztens, hanem azért, mert a sokk egy olyan strukturális változást generál, aminek következtében a hatása hosszú távon fennmarad: kibontakozik egy „fennmaradási hatás”, idegen szóval remanencia.

Amable és szerzőtársai [2004] amellett, hogy igyekszik bizonyítani, hogy az egységgyök/nullagyök modellek egyszerü perzisztenciájával ellentétben a valódi hiszterézismodellekben komplex remanencia figyelhető meg, felhívja a figyelmet arra, hogy empirikus szempontból is fontos különbség van a kétféle modellcsalád között. Az egységgyök/nullagyök modellek stacioner inputból nem stacioner outputot generálnak, a valódi hiszterézismodellek viszont stacioner inputból stacioner outputot. Ez a különbség egyben rávilágít arra, hogy nem kell feltétlenül nem stacioner folyamatokban gondolkodni, ha útfüggőségről beszélünk, hiszen stacioner folyamatok is lehetnek útfüggők, sőt hiszteretikusak. Amable és szerzötársai [2004] eredménye

\footnotetext{
${ }^{22}$ A következő alfejezetben kifejtjük, hogy a valódi hiszterézisnek létezik egy úgynevezett erős változata is. (Az előző alfejezetben a gyenge változat szerepelt.) Erős hiszterézis esetében a szelektív memória azt jelenti, hogy az inputváltozó dominált szélsőértékeire nem „emlékszik” a rendszer.
} 
érthetővé válik a 3. ábra hiszterézisoperátora alapján: látható, hogy az outputváltozó korlátos, nem léphet ki a $[0,1]$ intervallumból, tehát nem lehet se növekvő, se csökkenő trendje. A stacionaritás nem mond ellent a hiszterézisnek, hiszen továbbra is igaz, hogy amennyiben egy átmeneti sokk következtében az inputváltozó átlépi valamelyik küszöbértékét, a rendszer a hiszterézisoperátor másik ágára kerül, így permanens hatása lesz a sokknak. A szelektív memória tulajdonsága miatt azonban a nagy sokkok kitörlik a dominált sokkok hatását a rendszer memóriájából, ezáltal biztosítják, hogy az outputváltozó stacionaritása fennmaradhasson.

Az eddigiek alapján már egyértelmü, hogy a valódi hiszterézis több szempontból is egy jóval komplexebb útfüggő dinamikát takar, mint az egységgyök/nullagyök hiszterézis. Sőt az egységgyök/nullagyök folyamatokban tulajdonképpen semmi komplex nincs. Ennek a hátterében alapvetően az áll, hogy az egységgyök/nullagyök modellek lineárisak, a valódi hiszterézismodellek viszont nemlineárisak. Mindezek alapján rávilágíthatunk egy fontos szemléletbeli különbségre a két modellcsalád között: az egységgyök/nullagyök modellekben a hiszterézis az alapvetően ergodikus gazdasági dinamika egy kivételes, speciális esete, a valódi hiszterézismodellek nemlineáris világában viszont éppen a hiszterézis jelenti a gazdasági dinamika általános sajátosságát, miközben a lineáris struktúrában elöálló ergodikus gazdasági dinamika a speciális eset. Azért speciális eset az egységgyök/ nullagyök modellekben a hiszterézis, mert az szükséges hozzá, hogy a modellstruktúrát szolgáltató dinamikus rendszer együtthatómátrixának az egyik sajátértéke éppen eggyel (diszkrét időben) vagy nullával (folytonos időben) legyen egyenlő, egyéb esetekben nem jelenik meg a hiszterézis. Valódi hiszterézismodellekben ilyesmire nincs szükség, azokban a nemlineáris modellstruktúra miatt a hiszterézis eleve jelen van, és éppen a hiszterézis eltüntetéséhez van szükség egy speciális, lineáris modellstruktúrára.

A fenti kritikai megjegyzések tükrében Setterfield [1998] a hiszterézis egy olyan formális definícióját fogalmazta meg, amely alapján a fóáramú közgazdaságtan meghatározott (determinate) egyensúlyfogalmára épülö dinamika tekintendő a gazdasági dinamika speciális esetének, miközben a hiszterézis az általános eset. A definíció szerint egy dinamikus rendszerben akkor van jelen hiszterézis, ha „egy korábbi nem egyensúlyi alkalmazkodási pálya mentén való mozgás kumulatív hatása a rendszer struktúrájára és ezáltal a hosszú távú kimenetelére nem nulla" (Setterfield [1998] 292. o.). Tehát abban a speciális esetben nincs hiszterézis, ha ez a kumulatív hatás mégis nulla. Ez a szemlélet gyökeres ellentéte annak, amivel a föáramú közgazdászok munkáiban és az egységgyök/nullagyök modellekben találkozhatunk, vagyis ami szerint a gazdasági folyamatok dinamikáját általában egy egyértelmü, stabil egyensúlyi helyzet határozza meg, és bizonyos speciális feltételek mellett, kivételes esetben állhat elő hiszterézis.

Minden kritikai észrevétele ellenére Setterfield [2009] megjegyzi, hogy amennyiben nem célunk, hogy teljes komplexitásában modellezzük a gazdaság dinamikáját, akkor az egységgyök/nullagyök modellek az útfüggő gazdasági dinamika vizsgálatának hasznos kiindulópontjaként szolgálhatnak, egyszerüségük pedig mindenképpen nagy előny a valódi hiszterézismodellekhez képest. Szó sincs tehát arról, hogy meg kell feledkeznünk az egységgyök/nullagyök modellekről, de ha mélyebben szeretnénk megérteni az útfüggő gazdasági dinamika komplexitását, akkor nem kerülhetjük meg a valódi hiszterézismodellek használatát. 


\section{Erős és gyenge hiszterézis}

A Valódi hiszterézismodellek című alfejezetben bemutatott hiszterézisoperátor önmagában csak a valódi hiszterézis egy egyszerübb változatának, az úgynevezett gyenge hiszterézisnek a generálására képes. A gyenge hiszterézis a gazdaság mikroszintü jellemzője, amely az egyes gazdasági szereplők szintjén figyelhető meg (Amable és szerzötársai [1993], [1994], Göcke [2002], Setterfield [2009]). A tökéletesen versenyző vállalat korábban bemutatott piaci be- és kilépési döntéséhez visszatérve: a hiszterézisoperátor nyilvánvalóan csak egyetlen vállalat döntésének modellezésére alkalmas, hiszen makroszinten értelmezve azt implikálná, hogy vagy az összes olyan vállalat aktív, amely a piacon potenciálisan érdekelt lehet, vagy egyik sem. Ez nyilvánvalóan irreális. Nem oldja meg a problémát az sem, ha sok homogén vállalatot feltételezünk a modellben, amelyek közül elég egy reprezentatív vállalat viselkedését vizsgálnunk. Valósághü piaci dinamika modellezésére csak akkor van esélyünk, ha sok heterogén be- és kilépési küszöbárakkal rendelkező vállalat viselkedését modellezzük: ekkor előfordulhat, hogy adott piaci ár mellett a vállalatok egy része aktív a piacon, míg a maradék hányaduk inaktív.

Elegendően sok heterogén küszöbértékekkel jellemezhető hiszterézisoperátor aggregálásával erős hiszterézist produkálhatunk modellünkben. A gyenge hiszterézissel szemben az erős hiszterézis egy komplexebb útfüggő dinamikát takar, amely nem mikroszintü, hanem makroszintü jellemzője a gazdaságnak (Amable és szerzőtársai [1993], [1994], Göcke [2002], Setterfield [2009]). A lényegét ezúttal is a tökéletesen versenyző vállalat piaci be- és kilépési döntésén keresztül mutatjuk be, követve Göcke [2002] példáját, de ezúttal áttérve piaci szintre.

Tegyük fel, hogy elegendően sok, az egyszerüség kedvéért végtelen sok vállalat lehet érdekelt egy adott piacon. A vállalatok majdnem minden szempontból egyformák, egy fontos különbség kivételével: mindegyikük eltérő mértékủ fix költséggel szembesül a piacra történő belépéskor. Ez azt jelenti, hogy minden vállalat döntése leírható egy hiszterézisoperátorral, de ezek a hiszterézisoperátorok különfélék a belépési és a kilépési küszöbárak tekintetében. Ezeknek a heterogén küszöbértékekkel rendelkező hiszterézisoperátoroknak az aggregálása eredményezi az erős hiszterézist.

Tegyük fel azt is, hogy a piaci ár $(x)$ a 4. ábrán látható pályát írja le: elindul egy rendkívül alacsony értékről (az egyszerüség kedveeért 0 -ról) a 0 . periódusban, majd nagyot nő az 1. periódusban, ezután pedig egyik periódusban csökken, másikban nő oly módon, hogy a lokális minimumai és maximumai sosem múlják alul, illetve haladják meg az előzőt. Végül az 5. periódusban akkorát nő, hogy eléri a globális maximumát.

A piacon potenciálisan érdekelt vállalatok elhelyezhetők a be- és kilépési küszöbáraik ( $b$ és $a$ ) által definiált koordináta-rendszerben az 5. ábrán. Azon belül is csak a 45 fokos egyenes feletti terület releváns, hiszen $b>a$ : a belépési küszöbár minden vállalat esetében nagyobb a kilépési küszöbárnál. Egy vállalat a sík egy adott pontjaként jelenik meg a modellben: a pont függőleges koordinátája megadja a vállalat belépési küszöbárát, a vízszintes koordinátája pedig a kilépési küszöbárát.

Az 5. ábra bal felső részén látható a 0 . periódus induló szituációja. Ekkor a piaci ár 0 , ezért egyetlen vállalat sem aktív a piacon. Az 1. periódusban a piaci ár $x_{1}$-re nő. Azok a 
4. ábra

A piaci ár feltételezett alakulása a tökéletes versenyzői piacon

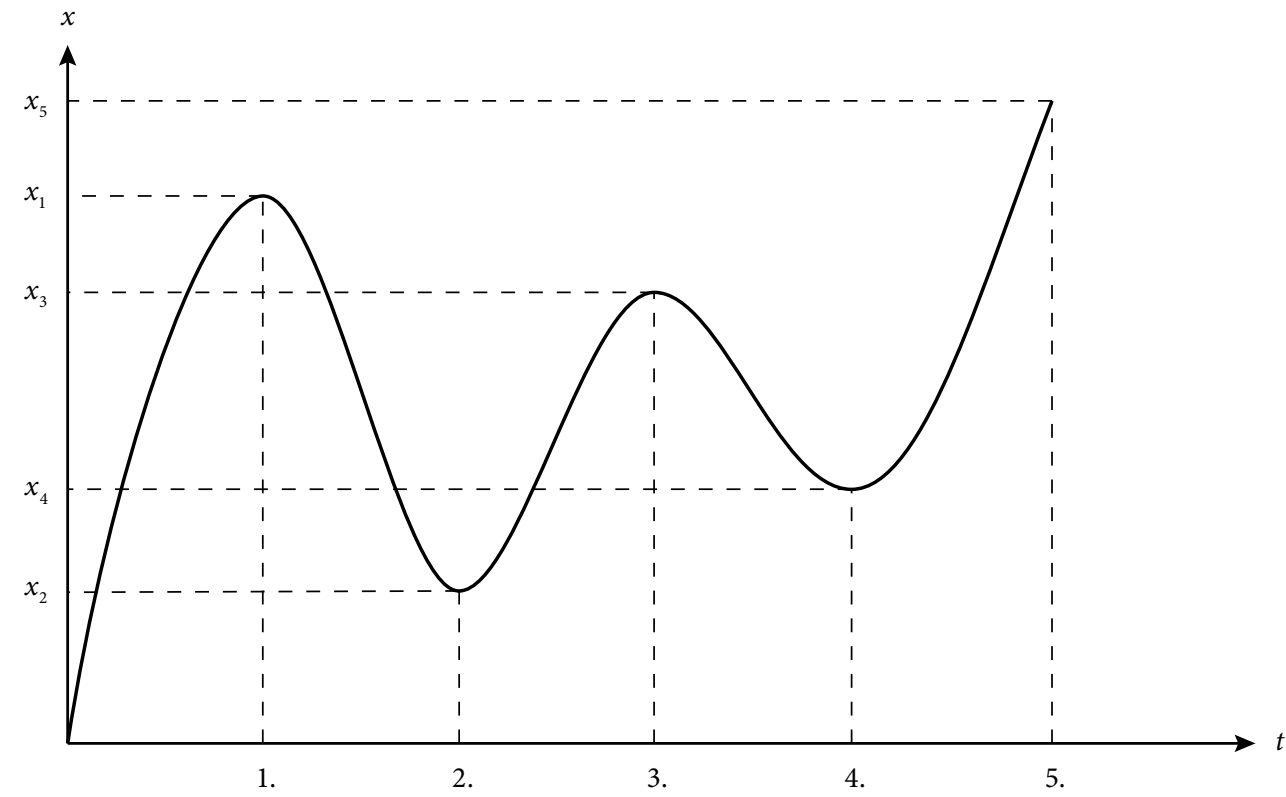

Forrás: saját szerkesztés.

vállalatok, amelyeknek $b$ belépési küszöbára kisebb ennél, belépnek a piacra. Az 5. ábra jobb felső részén a szürkével jelölt terület tartalmazza azokat a vállalatokat, amelyek aktívvá váltak. A 2. periódusban csökken az ár, de nem az eredeti 0 értékre, hanem $x_{2}$-re. Azok az aktív vállalatok, amelyek kilépési küszöbára nagyobb ennél, kilépnek a piacról. Az 5. ábra bal középső részén a szürke terület zsugorodása jelzi, hogy kevesebb az aktív vállalat a piacon, mint az 1. periódusban. Majd a 3. periódusban a piaci ár $x_{3}$-ra nő. $\mathrm{Az}$ ennél kisebb belépési küszöbárral rendelkező inaktív vállalatok belépnek a piacra, az 5 . ábra középső részének jobb oldalán megnő a szürke terület a középső rész bal oldalához képest. A 4. periódusban $x_{4}$-re csökken az ár, az ennél nagyobb kilépési küszöbárral rendelkező aktív vállalatok kilépnek a piacról, így az 5. ábra bal alsó részén valamelyest csökken a szürke terület nagysága a jobb középső részéhez képest. Végül az 5. periódusban megszakad az addigi mintázat: a piaci ár $x_{5}$-re nő, ezzel eléri globális maximumát, és kitörli az aktív vállalatokat tartalmazó terület addigi lépcsőzetes mintázatát, hiszen minden vállalat aktívvá válik, amelynek a belépési küszöbára $x_{5}$-nél kisebb.

Az 5. ábra legfontosabb tanulsága az, hogy a piacon aktív vállalatok száma útfüggő módon alakul ki. Nem elég az aktuális piaci árat ismernünk ahhoz, hogy meg tudjuk mondani, hány vállalat aktív a piacon, hiszen adott ár mellett többféle „szürke terület” is kialakulhat a belépési és kilépési küszöbárak koordinátarendszerében a piac „történelmétől”, vagyis a piaci ár által bejárt úttól függően. Nem kell azonban a piaci ár összes múltbeli értékét ismernünk, hiszen láttuk, hogy az 5. periódusban érkező extrém ársokk kitörölte a rendszer memóriáját. A piac releváns történelmét csupán az ár nem dominált szélsőértékeinek sorozata jelenti, 
5. ábra

Aktív vállalatok a tökéletes versenyzői piacon változó piaci ár mellett
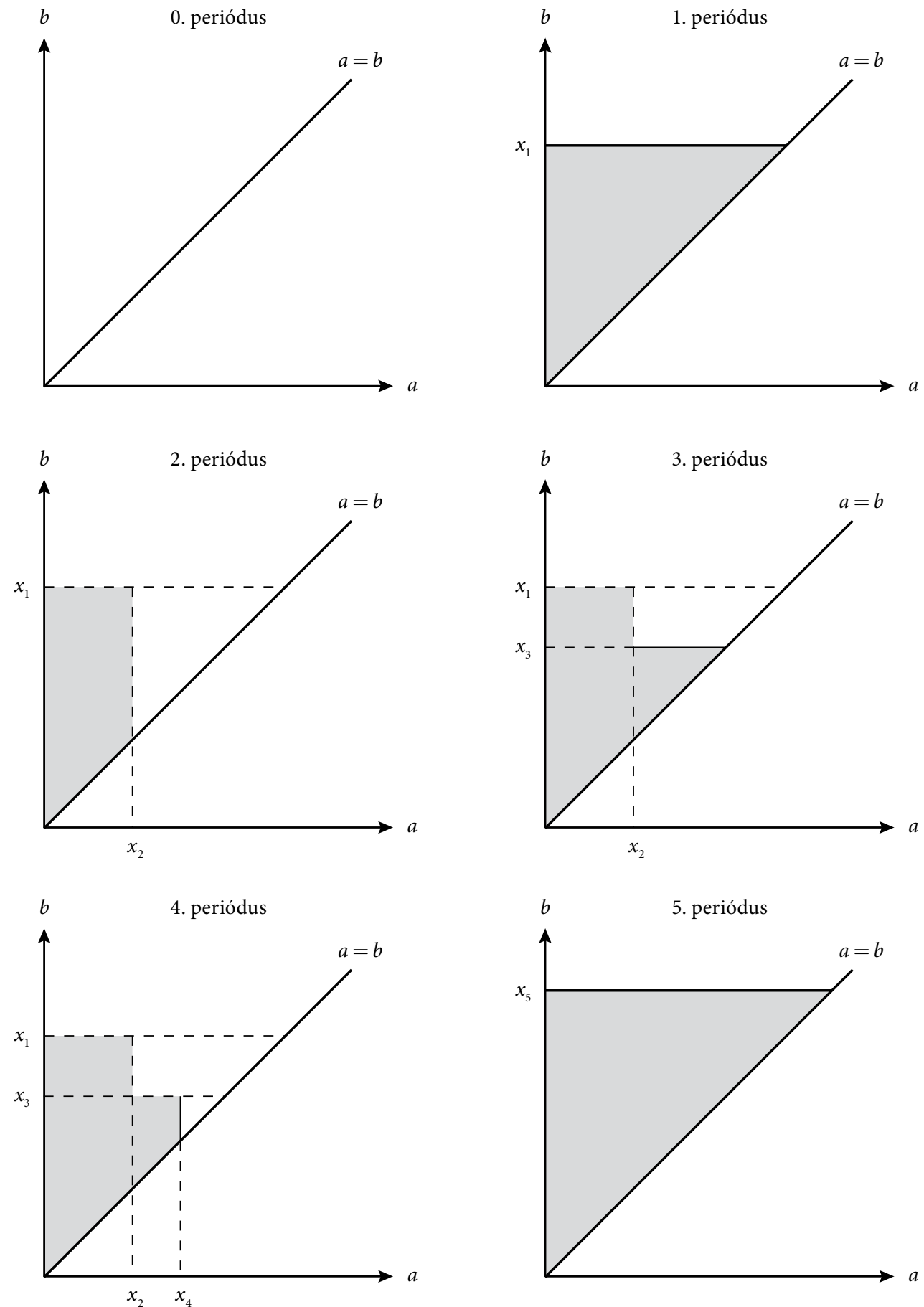

Forrás: saját szerkesztés Göcke [2002] alapján. 
vagyis az ár azon lokális maximumainak (minimumainak) a sorozata, amelyek bekövetkezése óta nem ért el nagyobb (kisebb) értéket.

Példánkban a piaci ár minden periódusban elért egy lokális szélsőértéket, de a 4. periódusig egyik sem dominálta az előzőket, ezért addig a periódusig minden korábbi ár fontos volt a piac történelme szempontjából. Az ár nem dominált maximumai a belépési küszöbár függőleges tengelye mentén alakítottak ki egy lépcsőt az aktív vállalatokat tartalmazó szürke területben, a nem dominált minimumok pedig a kilépési küszöbár vízszintes tengelye mentén. Az 5. periódusban a piaci ár elérkezett a globális maximumára, ami dominálta az összes korábbi maximumot, így azok kitörlődtek a rendszer memóriájából, és elvesztették a relevanciájukat a piac történelme szempontjából. Vizuálisan ez úgy jelent meg az 5. ábrán, hogy az aktív vállalatokat tartalmazó szürke területből eltüntek a lépcsők.

Elképzelhető lett volna egy olyan szituáció is, amelyben a piaci ár az 5. periódusban az 1. és a 3. periódusbeli érték közé került volna, vagyis $x_{3}<x_{5}<x_{1}$. Ekkor $x_{5}$ nem lett volna globális maximuma az árnak, de a 3. periódus lokális maximumát dominálta volna. Ennek következtében $x_{3}$ már nem határozta volna meg a továbbiakban a piac történelmét, $x_{1}$ viszont igen, hiszen az nem dominált szélsőérték maradt volna. Vizuálisan ez úgy képzelhető el, hogy az 5. ábra bal alsó részéhez képest a szürke területből eltűnt volna a függőleges tengely $x_{3}$ értékénél található lépcső, az $x_{1}$ értéknél található lépcsö viszont megmaradt volna.

Az 5. ábra első öt részében ábrázolt dinamika tömörebben is összefoglalható a 6 . ábrán. Itt az inputváltozó, vagyis a piaci ár $(x)$ értékei vannak felmérve a vízszintes tengelyre, a függőleges tengelyre pedig az aggregált outputváltozó, vagyis a piacon aktív vállalatok számának $(Y)$ értékei. A koordináta-rendszerben megjelölhetünk öt pontot, amelyek megmutatják, hogy a nulladiktól a negyedik periódusig a piaci ár és az aktív vállalatszám milyen kombinációit lehetett megfigyelni a piacon. Az egyes pontok mellé írt számok jelzik, hogy az adott pont az inputváltozó és az aggregált outputváltozó mely periódusbeli kombinációját testesíti meg. Ha összekötjük ezeket a pontokat, akkor kirajzolódik egy alakzat, amelyet hiszterézishuroknak (hysteresis loop) nevezünk. A hiszterézishurok egyfelől tükrözi a közgazdasági logikán alapuló intuíciót: a piaci ár és az aktív vállalatok száma között pozitív a kapcsolat. Másfelől az is látszik, hogy ez a pozitív kapcsolat nem lineáris: egy adott piaci ár mellett az aktív vállalatok számának többféle értéke is lehet egyensúlyi. Hogy a többféle egyensúlyi érték közül melyik alakul ki, az attól függ, hogy a piaci ár milyen úton jutott el az aktuális értékéhez. Ez a hiszterézishurok legfontosabb tanulsága.

Hogy pontosan milyen alakot ölt a hiszterézishurok, az attól függ, hogy milyen a heterogén vállalatok eloszlása a belépési és kilépési küszöbáraik koordinátarendszerében. A vállalatok folytonos eloszlása a 6. ábrán láthatóhoz hasonló, folytonos darabokból álló hiszterézishurkot eredményez. Ha viszont a vállalatok eloszlása diszkrét, akkor a hiszterézishurok darabjai „lépcsőzetesek” lesznek. A vállalatok eloszlása határozza meg a hiszterézishurok görbületét is. Minél kevésbé heterogének a vállalatok, annál inkább csoportosulnak az $(a, b)$ sík egy adott területén, így annál nagyobb lesz a hurok darabjainak görbülete. Szélsőséges esetben, amikor a vállalatok teljesen homogének, a hiszterézishurok hiszterézisoperátorrá egyszerüsödik. 


\section{6. ábra}

A hiszterézishurok

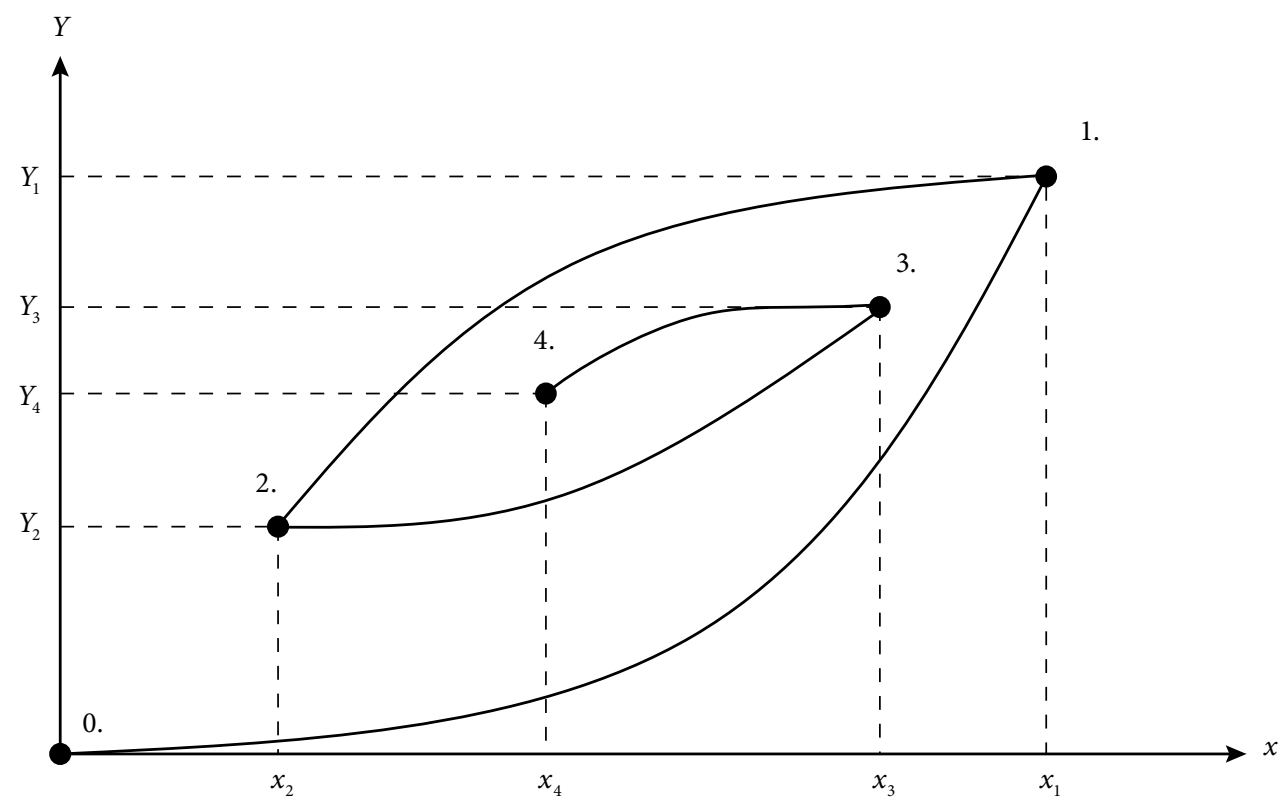

Forrás: saját szerkesztés Göcke [2002] alapján.

A valódi hiszterézis korábban felsorolt három tulajdonsága (irreverzibilitás, szuperreverzibilitás hiánya, szelektív memória) igaz a gyenge és az erős hiszterézisre egyaránt. Van azonban három további szempont, amelyek alapján az erős hiszterézis komplexebb útfüggő dinamikát takar, mint a gyenge hiszterézis (Amable és szerzőtársai [1994]).

1. Mi alkotja a történelmet? Másképpen fogalmazva: milyen információkat kell ismernünk az inputváltozó aktuális értéke mellett a rendszer múltbeli alkalmazkodási pályájáról ahhoz, hogy meg tudjuk állapítani az outputváltozó értékét? Gyenge hiszterézis esetén elég a változók kezdő értékeit ismernünk, továbbá azt, hogy az inputváltozó hányszor lépte át az alsó és a felső küszöbértéket. Erős hiszterézis esetén viszont láttuk, hogy az inputváltozó nem dominált szélsőértékeinek sorozata alkotja a történelmet.

2. Van-e a kis átmeneti sokkoknak permanens hatásuk? Gyenge hiszterézis esetén nincs: ahhoz, hogy egy átmeneti sokknak permanens hatása legyen az outputváltozóra, elég nagynak kell lennie ahhoz, hogy küszöbérték-átlépést generáljon. Erős hiszterézis mellett viszont tetszőlegesen kicsi átmeneti sokk is gyakorolhat tartós hatást az outputváltozóra, ha az elemi hiszterézisoperátorok elegendően heterogének a küszöbértékeik szempontjából. Ilyenkor ugyanis kis sokkok mellett is nagy valószínüséggel lesz legalább egy-két olyan hiszterézisoperátor, amelynél küszöbérték-átlépés történik, és ez már elég ahhoz, hogy makroszinten permanens hatása legyen az átmeneti sokknak.

3. Függ-e a remanencia mértéke az inputváltozót érő sokk nagyságától? A remanencia mértékén azt értjük, hogy az outputváltozó új egyensúlyi értéke mennyire 
kerül messze az eredetitől az inputváltozót érő átmeneti sokk következtében. Gyenge hiszterézis esetén ez nem függ attól, hogy mekkora sokk érte az inputváltozót: a 3. ábrán világosan látszik, hogy amennyiben az inputváltozó átlépi valamelyik küszöbértékét, akkor az outputváltozó alakulása szempontjából már mindegy, hogy menynyivel lépi át. Nem mondható el ugyanez erős hiszterézis esetén, akkor már függ a remanencia mértéke az inputváltozót érő sokk nagyságától. Nagyobb átmeneti sokk ugyanis több elemi hiszterézisoperátornál generál küszöbérték-átlépést, így makroszinten nagyobb permanens hatást fog gyakorolni az outputváltozóra.

A tanulmányban korábban hivatkozott valódi hiszterézismodellek többségében gyenge hiszterézis található. Kivétel ez alól Cross [1994] eszközválasztási modellje, amelyben a gazdasági szereplők heterogének az eszközváltási fix költség szempontjából, ezáltal a makroszintű vagyon hazai és külföldi devizában tartott arányainak dinamikájában erős hiszterézis alakul ki. További kivétel természetesen a - korábbiakban bemutatott - heterogén belépési fix költségekkel rendelkező versenyző vállalatok piaci be- és kilépési döntésének modellje. Ezt több hiszterézissel kapcsolatos áttekintő tanulmány használja példamodellként, akár egy hazai piacra (Göcke [2002]), akár a nemzetközi piacokra (Amable és szerzőtársai [1994]) való be- és kilépés összefüggésében. Létezik továbbá néhány empirikus munka, amelyek szerzői az erős hiszterézis logikáját felhasználva valós gazdasági idősorokból generáltak úgynevezett hiszterézisváltozókat, és ezek segítségével igyekeztek kimutatni az erős hiszterézis jelenlétét például a brit munkanélküliségi rátában (Darbyés szerzőtársai [2006]) vagy Okun törvényében (Lang-De Peretti [2009]). ${ }^{23}$

A hivatkozott tanulmányok mindegyikében komoly korlátként jelenik meg az, hogy az erős hiszterézist „intuitív” alapon, főként ábrák segítségével modellezik, számszerüsíthető modellekkel nem találkozhatunk bennük. ${ }^{24}$ Ennek az az oka, hogy az erős hiszterézis számszerüsíthető modellezéséhez sok heterogén küszöbértékekkel rendelkező hiszterézisoperátor aggregálására lenne szükség, ami analitikusan komoly nehézségekbe ütközik a hiszterézisoperátor nemlinearitása miatt. Tegyük fel például, hogy egy $y$ outputváltozó értékét egy $x$ inputváltozó adott értéke mellett egy $(a, b)$ küszöbértékpárral rendelkező $F_{a, b}(x)$ hiszterézisoperátor határozza meg. Jelölje továbbá $Y$ az aggregált outputváltozót, $g(a, b)$ pedig legyen egy súlyfüggvény, amely meghatározza, hogy a különböző $(a, b)$ küszöbértékpárokkal rendelkező hiszterézisoperátorok mekkora súllyal járulnak hozzá az aggregált outputváltozó alakulásához. Ekkor $Y$ értéke a $t$-edik időszakban elvileg a következőképpen számítható ki (Mayergoyz [1985]):

$Y_{t}=\iint_{b>a} g(a, b) F_{a, b}\left(x_{t}\right) d b d a$.

${ }^{23}$ A Lang-De Peretti [2009] empirikus elemzése mögött álló elméleti modellkeret alapján mutatja be az erős hiszterézist Setterfield [2009] is.

${ }^{24}$ Darby és szerzőtársai [2006], valamint Lang-De Peretti [2009] empirikus elemzéseiben sem az elméleti modell számszerüsítése történik meg, csupán a modell logikáját felhasználva hajtanak végre bizonyos hiszteretikus transzformációkat empirikus változókon, amelyeket aztán standard lineáris regressziós modellekbe illesztenek be. 
A (10) egyenletben szereplő kettős integrál kiszámítása azonban analitikusan komoly nehézségekbe ütközik a hiszterézisoperátor nemlinearitása miatt. Ez napjainkig jelentősen korlátozta az erős hiszterézis modelljeinek elterjedését.

Új lendületet adhat az erős hiszterézis modellezésének az ágensalapú modellek közgazdasági alkalmazásainak utóbbi években tapasztalható térnyerése. Az ágensalapú közgazdasági modellek a komplex, evolúciós rendszerekként felfogott gazdaságokat a legkisebb alkotóelemei (ágensei) szintjén ragadják meg, vagyis közvetlenül csak a gazdasági szereplők viselkedését és a köztük zajló interakciókat modellezik, a makroszintü jelenségek pedig ezekből bontakoznak ki numerikus szimulációk során, úgynevezett emergens jelenségekként. Emergens jelenségen olyan jelenségeket értünk, amelyek mikroszinten nem figyelhetők meg, de a mikroszintủ ágensek interakcióiból kibontakozva makroszinten már megfigyelhetők, és visszacsatolnak az ágensek mikroszintű viselkedésébe. Az ágensalapú közgazdasági modellek kulcssajátossága a reprezentatív háztartás és vállalat standard modellezési eszközeiröl való lemondás. Ezek alkalmazása helyett az ágensalapú modellekben minden gazdasági szereplő viselkedését explicit módon modellezzük (Tesfatsion [2006]).

Könnyen észrevehetjük, hogy az erős hiszterézis tipikus emergens jelenség: mikroszinten nem megfigyelhetö, viszont a mikroszintü döntések aggregálása után makroszinten kibontakozik. Mivel az ágensalapú modelleket kimondottan az emergens jelenségek modellezésére találták ki, az erős hiszterézis modellezésére is különösen alkalmasnak tűnnek. Egy ágensalapú modell keretei között elég csupán az elemi hiszterézisoperátorokat modelleznünk, és feltételeznünk, hogy a küszöbértékeik heterogének. A modell szimulálása során az outputváltozó mikroszintű értékei numerikusan aggregálhatók, így az aggregált outputváltozó dinamikáját és a benne rejlő erős hiszterézist is szimulálni tudjuk anélkül, hogy a (10) egyenlet kettős integrálját ki kellene számítanunk. Az ágensalapú modellek tehát megnyitják az utat az erős hiszterézis számszerüsíthető modellezése előtt.

Az ágensalapú modellek alkalmazásának gondolata az erős hiszterézis modellezésére viszonylag friss. Setterfield-Gouri Suresh [2016] vetette fel, hogy az ágensalapú modellek különösen alkalmasnak tünnek az erős hiszterézis és általában az útfüggő gazdasági dinamika modellezésére. A szerzők nemcsak azt emelték ki, hogy az ágensalapú modellekhez hasonlóan az útfüggőség számos modelljében is kulcsszerepet kapnak az emergens jelenségek, hanem azt is, hogy az ágensalapú modellek olyan komplex rendszereket írnak le, amelyeknek gyakori jellemzője a nemlinearitás és a kezdeti feltételekre való érzékenység, akárcsak az útfüggőség modelljeiben. Az útfüggőség számos modelljében nincs egyensúly, vagy ha van, akkor a valódi hiszterézismodellek kapcsán megfigyelt módon, dinamikusan változik. Az ilyen modellek többnyire analitikusan kezelhetetlenek, viszont az ágensalapú modellezés szimulációs technikaként lehetővé teszi, hogy ezeknek a modelleknek a viselkedését is elemezni tudjuk.

Egyelöre csupán két tanulmányról van tudomásunk, amelyeknek szerzői felismerték az ágensalapú modellek potenciálját az erös hiszterézis modellezésében: Setterfield-Gouri Suresh [2016] és Bassi-Lang [2016]. Ezek meglehetősen frissek, és elképzelhető, hogy a közeljövőben több új ágensalapú modell lát napvilágot, 
amelyeket erősen hiszteretikus gazdasági folyamatok szimulálására fognak kihegyezni. Véleményünk szerint a hiszterézissel kapcsolatos közgazdasági kutatások egyik legfőbb jövőbeli irányát az ágensalapú modellek erős hiszterézismodellekként történő alkalmazásai fogják jelenteni.

\section{Összefoglalás és a jövőbeli kutatások várható irányai}

A 2008-as gazdasági válságból való kilábalás során egy szokatlannak tűnő jelenséggel szembesültünk: a válság jelentette átmeneti sokk után a gazdaságok többsége nem tért vissza a válság előtti növekedési pályájára, hanem egy tartósan alacsonyabb szintű növekedési pályára állt rá. A tanulmány először összefoglalta az ezzel kapcsolatos empirikus megfigyeléseket. Az egyik legelterjedtebb magyarázat szerint a jelenség a gazdasági dinamika egy máig méltatlanul kevés figyelmet kapott típusának, a hiszterézisnek egy konkrét megnyilvánulása. Hiszterézisről akkor beszélünk, ha egy dinamikus rendszert érö átmeneti sokk permanens hatást gyakorol a rendszer hosszú távú egyensúlyára. A tanulmány rámutatott arra, hogy a hiszterézissel kapcsolatos közgazdasági gondolatok már jóval a közelmúlt gazdasági válsága előtt is időnként felbukkantak a szakirodalomban, és rövid áttekintést nyújtott a hiszterézis közgazdasági elmélettörténetéről, a hiszterézissel foglalkozó legfontosabb közgazdasági munkákról. Ezután amellett érvelt, hogy a hiszterézis közgazdasági jelentősége a posztkeynesi közgazdaságtan nézőpontjából érthető meg igazán, majd bemutatta a hiszterézis modellezésének alapvető eszközeit, a hiszterézis különböző típusait és azok tulajdonságait. Terjedelmi okokból nem tért ki a hiszterézis ökonometriai vonatkozásaira: a hiszterézis empirikus adatokon történő mérésének és identifikálásának módszereire, a publikált ökonometriai elemzések eredményeire és arra, hogy milyen problémákat vet fel a hiszterézis az ökonometriai előrejelzéseket illetően. Ezek a kérdések önmagukban is megérdemelnének egy külön tanulmányt.

Nem kérdés, hogy az elmúlt néhány évben jelentősen megélénkült a közgazdászok érdeklődése a hiszterézis iránt. Hogy ez az érdeklődés mennyire marad tartós, és milyen mértékben fog a hiszterézis gondolata beépülni a tudomány fóáramába, az azon múlik, hogy a fóáramú közgazdászok évek múltán csak egy érdekes anomáliaként fognak-e tekinteni a hiszterézisre, ami a 2008-as válság után felbukkant, vagy a posztkeynesi közgazdászokhoz hasonlóan a gazdasági dinamika általános jellemzőjeként. Elképzelhető egy köztes forgatókönyv is, amely szerint csak az egységgyök/nullagyök hiszterézis épül be a tudomány föáramába, mert az technikailag sokkal könnyebben beilleszthető a standard makromodellekbe, mint a valódi hiszterézis. Noha a valódi hiszterézis beillesztése sem lenne lehetetlen, hiszen a tanulmányban említettünk példákat valódi hiszterézist tartalmazó föáramú modellekre is.

Amellett viszont biztosan számos empirikus bizonyíték szól, hogy a 2008-as gazdasági válságból történő kilábalás alapjaiban kérdőjelezte meg az új neoklasszikus szintézis központi gondolatát, amely szerint egy gazdaság hosszú távú egyensúlyi növekedési pályája független a rövid távú ciklikus ingadozásaitól. Ez paradigmaváltásért kiált a makroökonómiában, a hiszterézisnek pedig az új paradigma egyik alapelemévé kell 
válnia, hiszen éppen a hiszterézis empirikus megfigyelése mutatott rá az újklasszikus és az újkeynesi közgazdászok közötti konszenzus tarthatatlanságára. Hogy a paradigmaváltás egy új makroökonómiai modellcsalád elterjedésében vagy a jelenleg uralkodó dinamikus sztochasztikus általános egyensúlyi modellek alkalmas finomításában fog-e megnyilvánulni, az egyelöre a jövő kérdése. Azt gondoljuk, hogy egy radikálisabb változás folyamatában kulcsszerepet kell szánni az ágensalapú modelleknek, amelyek véleményünk szerint már a közeljövőben forradalmasíthatják az erős hiszterézis modellezését.

\section{Hivatkozások}

Amable, B.-Henry, J.-Lordon, F.-Topol, R. [1993]: Unit Root in the Wage-Price Spiral Is Not Hysteresis in Unemployment. Journal of Economic Studies, Vol. 20. No. 1-2. 123-135. o. https://doi.org/10.1108/01443589310038551.

Amable, B.-Henry, J.-Lordon, F.-Topol, R. [1994]: Strong Hysteresis versus Zero Root Dynamics. Economic Letters, Vol. 44. No. 1-2. 43-47. o. https://doi.org/10.1016/01651765(93)00300-D.

Amable, B.-Henry, J.-Lordon, F.-Topol, R. [2004]: Complex Remanence vs. Simple Persistence: Are Hysteresis and Unit-Root Processes Observationally Equivalent? Megjelent: Barnett, W. A.-Deissenberger, C.-Feichtinger, G. (szerk.): International Symposia in Economic Theory and Econometrics. Vol. 14. Economic Complexity. Emerald Group Publishing, 67-89. o. https://doi.org/10.1108/s1571-0386(2004)0000014006.

Arestis, P.-SAwyer, M. [2009]: Path Dependency and Demand-Supply Interactions in Macroeconomic Analysis. Megjelent: Arestis, P.-Sawyer, M. (szerk.): Path Dependency and Macroeconomics. Palgrave Macmillan, London, 1-36. o. https://doi.org/10.1057/ 9780230251090_1.

ArthuR, W. B. [1989]: Competing Technologies, Increasing Returns, and Lock-In by Historical Events. The Economic Journal, Vol. 99. No. 394. 116-131. o. https://doi.org/10.2307/2234208.

Baldwin, R.-Krugman, P. R. [1989]: Persistent Trade Effects of Large Exchange Rate Shocks. The Quarterly Journal of Economics, Vol. 104. No. 4. 635-654. o. https://doi. org/10.2307/2937860.

BALL, L. M. [1999]: Aggregate Demand and Long-Run Unemployment. Brookings Papers on Economic Activity, Vol. 1999. No. 2. 189-251. o. https://doi.org/10.2307/2534680.

BALL, L. M. [2009]: Hysteresis in Unemployment: Old and New Evidence. NBER Working Paper, No. 14818. https://doi.org/10.3386/w14818.

BALL, L. M. [2014]: Long-Term Damage from the Great Recession in OECD Countries. European Journal of Economics and Economic Policies: Intervention, Vol. 11. No. 2. 149-160. o. https://doi.org/10.4337/ejeep.2014.02.02.

BALL, L. M. [2015]: Monetary Policy for a High-Pressure Economy. Center on Budget and Policy Priorities, Full Employment Project. Letöltve: Johns Hopkins University Department of Economics, http://www.econ2.jhu.edu/People/Ball/HighPressure.pdf.

Bassi, F.-LAnG, D. [2016]: Investment Hysteresis and Potential Output: A Post-KeynesianKaleckian Agent-Based Approach. Economic Modelling, Vol. 52. Part A, 35-49. o. https:// doi.org/10.1016/j.econmod.2015.06.022.

BÉLYÁCz IvÁN [2013]: Várakozások, bizonytalanság, valószínűség. Értekezés a kockázat számszerüsítésének korlátairól. Közgazdasági Szemle, 60. évf. 7-8. sz. 749-780. o. 
BÉLYÁCz IváN [2017]: Az ergodicitás vitatott szerepe a (pénzügyi) közgazdaságtanban. Eszmetörténeti értekezés az ergodikus hipotézis közgazdasági alkalmazhatóságáról. Gazdaság és Pénzügy, 4. évf. 1. sz. 3-58. o.

BlanCHARD, O. J. [2006]: European Unemployment. The Evolution of Facts and Ideas. Economic Policy, Vol. 21. No. 45. 6-59. o. https://doi.org/10.1111/j.1468-0327.2006.00153.x.

Blanchard, O. J.-Summers, L. H. [1986]: Hysteresis and the European Unemployment Problem. NBER Macroeconomics Annual, Vol. 1. 15-78. o. https://doi.org/10.1086/654013.

Blanchard, O. J.-Summers, L. H. [1987]: Hysteresis in Unemployment. European Economic Review, Vol. 31. No. 1-2. 288-295. o. https://doi.org/10.1016/0014-2921(87)90042-0.

Blanchard, O. J.-Cerutti, E.-Summers, L. H. [2015]: Inflation and Activity. Two Explorations and Their Monetary Policy Implications. NBER Working Paper, No. 21726. https:// doi.org/10.3386/w21726.

Borio, C. [2014]: The Financial Cycle and Macroeconomics. What Have We Learnt? Journal of Banking \& Finance, Vol. 45. 182-198. o. https://doi.org/10.1016/j.jbankfin.2013.07.031.

Borio, C.-Disyatat, P.-Juselius, M. [2017]: Rethinking Potential Output: Embedding Information about the Financial Cycle. Oxford Economic Papers, Vol. 69. No. 3. 655-677. o. https://doi.org/10.1093/oep/gpw063.

Cecchetti, S. G.-Kharroubi, E. [2015]: Why Does Financial Sector Growth Crowd Out Real Economic Growth? BIS Working Papers, No. 490.

Cooper, R. W.-Haltiwanger, J. C. [2006]: On the Nature of Capital Adjusment Costs. The Review of Economic Studies, Vol. 73. No. 3. 611-633. o. https://doi.org/10.1111/j.1467937X.2006.00389.x.

Cooper, R. W.-Haltiwanger, J. C.-Power, L. [1999]: Machine Replacement and the Business Cycle. Lumps and Bumps. The American Economic Review, Vol. 89. No. 4. 921-946. o. https://doi.org/10.3386/w5260.

Cross, R. B. [1987]: Hysteresis and Instability in the Natural Rate of Unemployment. The Scandinavian Journal of Economics, Vol. 89. No. 1. 71-89. o. https://doi.org/10.2307/3440485.

Cross, R. B. [1993]: On the Foundations of Hysteresis in Economic Systems. Economics and Philosophy, Vol. 9. No. 1. 53-74. o. https://doi.org/10.1017/s0266267100005113.

Cross, R. B. [1994]: The Macroeconomic Consequences of Discontinuous Adjustment: Selective Memory of Non-Dominated Extrema. Scottish Journal of Political Economy, Vol. 41. No. 2. 212-221. o. https://doi.org/10.1111/j.1467-9485.1994.tb01121.x.

Cross, R. B. [1995]: Is the Natural Rate Hypothesis Consistent with Hysteresis? Megjelent: Cross, R. B. (szerk.): The Natural Rate of Unemployment: Reflections on 25 Years of the Hypothesis. Cambridge University Press, Cambridge, 181-200. o. https://doi.org/10.1017/ cbo9780511559631.011.

Darby, J.-Cross, R. B.-Piscitelli, L. [2006]: Hysteresis and Unemployment. A Preliminary Investigation. Megjelent: Bertotti, G.-Mayergoyz, I. D. (szerk.): The Science of Hysteresis. Vol. 1. Mathematical Modeling and Applications. Academic Press, 667-699. o. https://doi. org/10.1016/b978-012480874-4/50011-7.

Davidson, P. [1982-1983]: Rational Expectations: A Fallacious Foundation for Studying Crucial Decision-Making Processes. Journal of Post Keynesian Economics, Vol. 5. No. 2. 182-198. o. https://doi.org/10.1080/01603477.1982.11489355.

Davidson, P. [1996]: Reality and Economic Theory. Journal of Post Keynesian Economics, Vol. 18. No. 4. 479-508. o. https://doi.org/10.1080/01603477.1996.11490083.

Delgado, F. A. [1991]: Hysteresis, Menu Costs, and Pricing with Random Exchange Rates. Journal of Monetary Economics, Vol. 28. No. 3. 461-484. o. https://doi. org/10.1016/0304-3932(91)90035-M. 
Dixit, A. K. [1989]: Hysteresis, Import Penetration, and Exchange Rate Pass-Through. The Quarterly Journal of Economics, Vol. 104. No. 2.205-228. o. https://doi.org/10.2307/2937845.

Dixit, A. K. [1991]: Analytical Approximations in Models of Hysteresis. The Review of Economic Studies, Vol. 68. No. 1. 141-151. o. https://doi.org/10.2307/2298051.

Dixit, A. K. [1992]: Investment and Hysteresis. The Journal of Economic Perspectives, Vol. 6. No. 1. 107-132. o. https://doi.org/10.1257/jep.6.1.107.

Dosi, G.-Egidi, M. [1991]: Substantive and Procedural Uncertainty. An Exploration of Economic Behaviours in Changing Environments. Journal of Evolutionary Economics, Vol. 1. No. 2. 145-168. o. https://doi.org/10.1007/BF01224917.

Durlauf, S. N. [1993]: Nonergodic Economic Growth. The Review of Economic Studies, Vol. 60. No. 2. 349-366. o. https://doi.org/10.2307/2298061.

Dut , A. K. [2006]: Aggregate Demand, Aggregate Supply and Economic Growth. International Review of Applied Economics, Vol. 20. No. 3. 319-336. o. https://doi. org/10.1080/02692170600736094.

Eggertsson, G. B.-Mehrotra, N. R. [2014]: A Model of Secular Stagnation. NBER Working Paper, No. 20574. https://doi.org/10.3386/w20574.

EwING, J. A. [1881]: On the Production of Transient Electric Currents in Iron and Steel Conductors by Twisting Them When Magnetised or by Magnetising Them When Twisted. Proceedings of the Royal Society of London, Vol. 33. 21-23. o. https://doi.org/10.1098/ rspl.1881.0067.

Fatás, A.-Summers, L. H. [2016]: The Permanent Effects of Fiscal Consolidations. NBER Working Paper, No. 22374. https://doi.org/10.3386/w22374.

Galí, J. [2008]: Monetary Policy, Inflation and the Business Cycle: An Introduction to the New Keynesian Framework. Princeton University Press, Princeton.

Galí, J. [2015]: Hysteresis and the European Unemployment Problem Revisited. NBER Working Paper, No. 21430. https://doi.org/10.3386/w21430.

GiavazzI, F.-Wyplosz, C. [1985]: The Zero Root Problem. A Note on the Dynamic Determination of the Stationary Equilibrium in Linear Models. The Review of Economic Studies, Vol. 52. No. 2. 353-357. o. https://doi.org/10.2307/2297627.

Göcke, M. [2002]: Various Concepts of Hysteresis Applied in Economics. Journal of Economic Surveys, Vol. 16. No. 2. 167-188. o. https://doi.org/10.1111/1467-6419.00163.

HALL, R. E. [2014]: Quantifying the Lasting Harm to the U.S. Economy from the Financial Crisis. NBER Macroeconomics Annual, Vol. 29. No. 1. 71-128. o. https://doi. org/10.1086/680584.

Hamilton, J. D. [1994]: Time Series Analysis. Princeton University Press, Princeton.

Kaldor, N. [1934]: A Classificatory Note on the Determinateness of Equilibrium. The Review of Economic Studies, Vol. 1. No. 2. 122-136. o. https://doi.org/10.2307/2967618.

Kaldor, N. [1957]: A Model of Economic Growth. The Economic Journal, Vol. 67. No. 268. 591-624. o. https://doi.org/10.2307/2227704.

KaLdoR, N. [1981]: The Role of Increasing Returns, Technical Progress and Cumulative Causation in the Theory of International Trade and Economic Growth. Economie Appliquée, Vol. 34. No. 4. 593-617. o.

Keynes, J. M. [1921]: A Treatise on Probability. MacMillan and Co., London.

Knight, F. H. [1921]: Risk, Uncertainty and Profit. Hart, Schaffner and Marx-Houghton Mifflin Co., Boston.

Koo, R. C. [2011]: The World in Balance Sheet Recession. Causes, Cures and Politics. RealWorld Economics Review, No. 58. 19-37. o. 
Krasznoszelszkij, M. A.-Pokrovszkij, A. V. [1983]: Sistemy s Gisteresisom. Nauka, Moszkva.

Krugman, P. R. [1991]: Increasing Returns and Economic Geography. Journal of Political Economy, Vol. 99. No. 3. 483-499. o. https://doi.org/10.1086/261763.

Lang, D.-De Peretti, C. [2009]: A Strong Hysteretic Model of Okun's Law: Theory and a Preliminary Investigation. International Review of Applied Economics, Vol. 23. No. 4. 445-462. o. https://doi.org/10.1080/02692170902954775.

Lavoie, M. [2006]: A Post-Keynesian Amendment to the New Consensus on Monetary Policy. Metroeconomica, Vol.57.No.2.165-192.o.https://doi.org/10.1111/j.1467-999x.2006.00238.x.

Lavoie, M. [2009]: Taming the New Consensus. Hysteresis and Some Other Post Keynesian Amendments. Megjelent: Fontana, G.-Setterfield, M. (szerk.): Macroeconomic Theory and Macroeconomic Pedagogy. Palgrave Macmillan, London, 191-213. o. https://doi. org/10.1007/978-0-230-29166-9_11.

Lavoie, M. [2014]: Post-Keynesian Economics. New Foundations. Edward Elgar, Cheltenham-Northampton, https://doi.org/10.4337/9781783475827.

Mayergoyz, I. D. [1985]: Hysteresis Models from the Mathematical and Control Theory Points of View. Journal of Applied Physics, Vol. 57. No. 1. 3803-3805. o. https://doi. org/10.1063/1.334925.

Meeks, G. [1991]: Keynes on the Rationality of Decision Procedures under Uncertainty. The Investment Decision. Megjelent: Meeks, G. (szerk.): Thoughtful Economic Man: Essays on Rationality, Moral Rules and Benevolence. Cambridge University Press, Cambridge, 126-160. o.

Mellár Tamás [2010]: Válaszút előtt a makroökonómia? Közgazdasági Szemle, 57. évf. 7-8. Sz. 591-611. o.

Mellár TAMÁs-NÉMETH KRISTÓF [2018]: A kibocsátási rés becslése többváltozós állapottérmodellekben. Szuperhiszterézis és további empirikus eredmények. Közgazdasági Szemle, 65. évf. 6. sz. 557-591. o. https://doi.org/10.18414/KSZ.2018.6.557.

MNB [2016]: Növekedési jelentés, 2016. Magyar Nemzeti Bank, Budapest, https://www.mnb. hu/letoltes/novekedesi-jelentes-2016-hu.PDF.

Murphy, K. M.-Shleifer, A.-VIshny, R. W. [1989]: Industrialization and the Big Push. Journal of Political Economy, Vol. 97. No. 5. 1003-1026. o. https://doi.org/10.1086/261641.

Myrdal, G. [1957]: Economic Theory and Underdeveloped Regions. Duckworth, London.

O'Donnell, R. [2013]: Two Post-Keynesian Approaches to Uncertainty and Irreducible Uncertainty. Megjelent: Harcourt, G. C.-Kriesler, P. (szerk.): The Oxford Handbook of Post-Keynesian Economics. Vol. 2. Critiques and Methodology. Oxford University Press, New York, 124-142. o. https://doi.org/10.1093/oxfordhb/9780195390759.013.0005.

OKun, A. M. [1973]: Upward Mobility in a High-Pressure Economy. Brookings Papers on Economic Activity, Vol. 1973. No. 1. 207-261. o. https://doi.org/10.2307/2534087.

Phelps, E. S. [1972]: Inflation Policy and Unemployment Theory. Macmillan, London.

Preisach Ferenc [1935]: Über die magnetische Nachwirkung. Zeitschrift für Physik, Vol. 94. No. 5-6. 277-302. o. https://doi.org/10.1007/BF01349418.

Rosser, J. B. [2011]: Post-Keynesian Perspectives and Complex Ecologic-Economic Dynamics. Metroeconomica, Vol. 62. No. 1. 96-121. o. https://doi.org/10.1111/j.1467999x.2010.04094.x.

RundE, J. [1990]: Keynesian Uncertainty and the Weight of Arguments. Economics and Philosophy, Vol. 6. No. 2. 275-292. o. https://doi.org/10.1017/s0266267100001255.

Setterfield, M. [1998]: Adjustment Asymmetries and Hysteresis in Simple Dynamic Models. The Manchester School, Vol. 66. No. 3. 283-301. o. https://doi.org/10.1111/1467-9957.00102. 
Setterfield, M. [2002]: A Model of Kaldorian Traverse: Cumulative Causation, Structural Change and Evolutionary Hysteresis. Megjelent: Setterfield, M. (szerk.): The Economics of Demand-Led Growth: Challenging the Supply-Side Vision of the Long Run. Edward Elgar, Cheltenham-Northampton, 215-233. o. http://dx.doi.org/10.4337/1840641770.00022.

Setterfield, M. [2009]: Path Dependency, Hysteresis and Macrodynamics. Megjelent: Arestis, P.-Sawyer, M. (szerk.): Path Dependency and Macroeconomics. Palgrave Macmillan, London, 37-79. o. https://doi.org/10.1057/9780230251090_2.

Setterfield, M.-Gouri Suresh, S. [2016]: Multi-Agent Systems as a Tool for Analyzing Path-Dependent Macrodynamics. Structural Change and Economic Dynamics, Vol. 38. 25-37. o. https://doi.org/10.1016/j.strueco.2016.03.001.

Shackle, G. L. S. [1955]: Uncertainty in Economics and Other Reflections. Cambridge University Press, Cambridge.

Stockhammer, E.-STurn, S. [2012]: The Impact of Monetary Policy on Unemployment Hysteresis. Applied Economics, Vol. 44. No. 21. 2743-2756. o. https://doi.org/10.1080/000 36846.2011.566199.

Storm, S.-NaAstepad, C. W. M. [2012]: Macroeconomics Beyond the NAIRU. Harvard University Press, Cambridge, https://doi.org/10.4159/harvard.9780674063242.

Tesfatsion, L. [2006]: Agent-Based Computational Economics: A Constructive Approach to Economic Theory. Megjelent: Tesfatsion, L.-Judd, K. L. (szerk.): Handbook of Computational Economics. Vol. 2. Agent-Based Computational Economics. Handbooks in Economics Series, North-Holland, 831-880. o. https://doi.org/10.1016/S1574-0021(05)02016-2.

VERdoorn, P. J. [1949]: Fattori che regolano lo sviluppo della produttivitá del lavoro. L'Industria.

Woodford, M. [2003]: Interest and Prices: Foundations of a Theory of Monetary Policy. Princeton University Press, Princeton.

Young, A. A. [1928]: Increasing Returns and Economic Progress. The Economic Journal, Vol. 38. No. 152. 527-542. o. https://doi.org/10.2307/2224097. 